\title{
Three-dimensional dust aerosol distribution and extinction climatology over northern Africa simulated with the ALADIN numerical prediction model from 2006 to 2010
}

\author{
M. Mokhtari ${ }^{1,2}$, P. Tulet ${ }^{1,3}$, C. Fischer ${ }^{1}$, Y. Bouteloup ${ }^{1}$, F. Bouyssel ${ }^{1}$, and O. Brachemi ${ }^{2}$ \\ ${ }^{1}$ CNRM/GAME, Météo-France, UMR3589, CNRS, Toulouse, France \\ ${ }^{2}$ Office National de la Météorologie (ONM), Algiers, Algeria \\ ${ }^{3}$ LACy, Université de La Réunion, Météo-France, UMR8105, CNRS, Saint-Denis de La Réunion, France \\ Correspondence to: M. Mokhtari (m_morad06@yahoo.fr) and P. Tulet (pierre.tulet@univ-reunion.fr)
}

Received: 26 January 2015 - Published in Atmos. Chem. Phys. Discuss.: 27 February 2015

Revised: 28 June 2015 - Accepted: 9 July 2015 - Published: 14 August 2015

\begin{abstract}
The seasonal cycle and optical properties of mineral dust aerosols in northern Africa were simulated for the period from 2006 to 2010 using the numerical atmospheric model ALADIN (Aire Limitée Adaptation dynamique Développement InterNational) coupled to the surface scheme SURFEX (SURFace EXternalisée). The particularity of the simulations is that the major physical processes responsible for dust emission and transport, as well as radiative effects, are taken into account on short timescales and at mesoscale resolution. The aim of these simulations is to quantify the dust emission and deposition, locate the major areas of dust emission and establish a climatology of aerosol optical properties in northern Africa. The mean monthly aerosol optical thickness (AOT) simulated by ALADIN is compared with the AOTs derived from the standard Dark Target (DT) and Deep Blue (DB) algorithms of the Aqua-MODIS (MODerate resolution Imaging Spectroradiometer) products over northern Africa and with a set of sun photometer measurements located at Banizoumbou, Cinzana, Soroa, Mbour and Cape Verde. The vertical distribution of dust aerosol represented by extinction profiles is also analysed using CALIOP (Cloud-Aerosol Lidar with Orthogonal Polarization) observations.
\end{abstract}

The annual dust emission simulated by ALADIN over northern Africa is $878 \mathrm{Tg}_{\text {year }}{ }^{-1}$. The Bodélé Depression appears to be the main area of dust emission in northern Africa, with an average estimate of about $21.6 \mathrm{Tg}_{\mathrm{gear}}{ }^{-1}$.

The simulated AOTs are in good agreement with satellite and sun photometer observations. The positions of the max- ima of the modelled AOTs over northern Africa match the observed positions, and the ALADIN simulations satisfactorily reproduce the various dust events over the 2006-2010 period.

The AOT climatology proposed in this paper provides a solid database of optical properties and consolidates the existing climatology over this region derived from satellites, the AERONET network and regional climate models. Moreover, the 3-D distribution of the simulated AOTs also provides information about the vertical structure of the dust aerosol extinction.

\section{Introduction}

Mineral dust aerosol dominates the aerosol mass over some continental regions, with relatively higher concentrations accounting for about $35 \%$ of the total aerosol mass (IPCC, 2013). These terrigenous particles transported by the atmosphere significantly alter the Earth's radiative budget by absorbing and scattering incoming solar and outgoing terrestrial radiation (Haywood et al., 2001; Sokolik et al., 2001, Houghton et al., 2001). They can affect cloud properties by modifying their radiative properties and precipitation (IPCC, 2007; Twomey, 1959; Albrecht, 1989; Sandu et al., 2008). They also play several roles in biogeochemical cycles (Martin, 1991; Swap et al., 1992), atmospheric chemistry (Wang et al., 2002; Martin et al., 2003), visibility and human health. Because of the important role that dust might play in future 
climate change and its potential high impact on the Earth's ecosystems and natural and human environments, it is important to know where the major dust sources are, how dust concentration varies in space and time, and what controls this variability. Northern Africa is the world's main source of dust aerosol, with a relative contribution of about $50 \%$ of the total worldwide production (Zender et al., 2003). This region is well suited for studying the impact of aerosols on the radiation budget and climate. Therefore, an accurate database of aerosol content in this region is crucial to identify and quantify this impact, particularly in regional climate models (RCMs). Changes to this database in numerical models have a sensitive impact on model performance. For example, various studies (Tompkins et al., 2005; Rodwell, 2005) have shown the positive impact of the switch from the Tanré et al. (1984) climatology to the Tegen et al. (1997) climatology for various aspects of the ECMWF model (Morcrette et al., 2009). Tompkins et al. (2005) have performed two 5day forecasts of the African easterly jet (AEJ) with the old and new climatology, and the results are compared with highresolution dropsonde data from the JET2000 campaign. The results of these simulations show that the new aerosol climatology significantly improves some aspects of the AEJ structure and strength. In the same study, 4 months of 5day forecasts were realized and compared using the contrasting aerosol distributions. The results show a clear improvement with the new climatology, with the jet strengthened, elongated to the east and less zonal, in agreement with the analyses. The new climatology suppresses deep convection by stabilizing the atmosphere, preventing the ITCZ (intertropical convergence zone) from progressively migrating north during the forecast. A strong reduction in mean equivalent potential temperature at the lowest model level is noted, with the southerly displacement of the ITCZ. More recently, Kocha et al. (2012) have shown the impact of dust storms on the cold extratropical outbreak and on the African easterly jet.

Today, several data sets for aerosol parameters in northern Africa are available. The Aerosol Robotic Network (AERONET; http://aeronet.gsfc.nasa.gov/; Holben et al., 1998), with its specifically designed geographical coverage, provides a robust database of aerosol optical thickness, while the data themselves describe local characteristics at station positions. Satellite products allow the spatial and temporal variability in atmospheric dust aerosol concentrations to be studied (Brooks and Legrand, 2000; Prospero et al., 2002; Washington et al., 2003). These products provide a 2-D horizontal representation of dust plumes and offer maximum spatial coverage. Numerous studies have been conducted to reproduce the dust aerosol contents in northern Africa based on this type of data. For example, Engelstaedter et al. (2006) used the TOMS (Total Ozone Mapping Spectrometer) AAI (Absorbing Aerosol Index) product from 1980 to 1992 to identify Saharan dust source regions and create a qualitative description of the annual dust cycle.
In the infrared spectrum, the Meteosat IDDI (Infrared Difference Dust Index) products are also available. Brooks and Legrand (2000) used IDDI to identify the location of the dust emission regions over northern Africa for the period 1984-1993. In addition, very high-resolution AOT (aerosol optical thickness) data are now available from satellites such as MODIS, MISR (Multi-angle Imaging SpectroRadiometer) and SEAWIFS (Sea-viewing Wide Field-of-view Sensor) and inversion codes such as Deep Blue (http://gdata1.sci.gsfc.nasa.gov/daac-bin/G3/gui. cgi?instance_id=aerosol_daily). Indeed, a recent comparative study (Bréon et al., 2011) between AOTs derived from POLDER (Polarization and Directionality of Earth's Reflectances), MODIS, MERIS (Medium Resolution Imaging Spectrometer), SEVIRI (Spinning Enhanced Visible and Infrared Imager) and CALIOP (Cloud-Aerosol Lidar with Orthogonal Polarization) shows that MODIS has the most reliable estimate of total AOT over ocean and land. However, these data encompass the collective contributions of maritime, continental and desert dust aerosols. Furthermore, the quality of satellite dust products is affected by a number of uncertainties related to the spatial and temporal resolution, atmospheric conditions and range of wavelengths used by each satellite. These error sources are thoroughly discussed in Schepanski et al. (2012). For example, Kocha et al. (2013) have indicated that the specific transit time of MODIS over western Africa generates a bias in the AOT dust retrieval due to the diurnal cycle of atmospheric processes such as convection and the early morning low-level jet.

Numerical modelling provides a 3-D view of the atmosphere and can be used to evaluate the individual role of each parameter involved in the optical thickness. The Tegen et al. (1997) climatology gives an average distribution valid for 1 year (1990), obtained from a combination of global distributions of aerosol data from different transport models for soil dust (Tegen and Fung, 1995), sea salt (Tegen et al., 1997), sulfates (Chin et al., 1996) and carbonaceous aerosols (Liousse et al., 1996). However, due to its low spatial resolution $\left(5^{\circ} \times 4^{\circ}\right)$, the content of dust aerosol over northern Africa is not well represented. Recently, Kinne et al. (2013) proposed a new monthly global climatology, MAC-v1 (Max Planck Institute Aerosol Climatology version 1) with a $1^{\circ} \times 1^{\circ}$ resolution. This climatology addresses three aerosol properties, namely the AOT, which provides information on the amount of aerosol; the SSA (single-scattering albedo), which provides information on absorption; and the Ap (Ångstrøm parameter), which provides information on size distribution.

Based on both satellite-derived monthly AOTs and a regional and chemistry model, Nabat et al. (2013) proposed a 3-D monthly climatology of aerosol distribution over the Mediterranean Sea for the 1979-2009 period and at a $50 \mathrm{~km}$ resolution.

Initiatives have already been taken to use operational numerical weather prediction (NWP) and regional models at a 
high resolution and on short timescales. These efforts include the WMO Sand and Dust Storm Warning Advisory and Assessment System (SDS-WAS, http://sds-was.aemet.es) program, whose "mission is to achieve comprehensive, coordinated and sustained observations and modeling capabilities of sand and dust storms in order to improve the monitoring of sand and dust storms to increase the understanding of the dust processes and to enhance dust prediction capabilities". The SDS-WAS system "is established as a federation of partners organized around regional nodes" (both quotations from https://www.wmo.int/pages/prog/arep/wwrp/ new/Sand_and_Dust_Storm.html) (northern-Africa-MiddleEast-Europe Node and Asian Node). About 16 dust prediction models have been used in SDS-WAS, such as BSCDREAM8b (Barcelona Supercomputing Center - Dust REgional Atmospheric Model, 8-bin version), MACC-ECMWF, INCA-LMDZT, CHIMERE, SKIRON, ETA, NGAC and NAAPS.

In this study, data and results from simulations using the ALADIN (Aire Limitée Adaptation dynamique Développement InterNational) model over northern Africa from 2006 to 2010 are presented. This model takes into account the different physical processes responsible for the emission, transport and deposition of dust. The aim of these simulations is to quantify the annual and seasonal emissions, locate the main emission dust sources and establish a climatology of dust aerosol optical properties in northern Africa. The mean monthly aerosol optical thickness simulated by ALADIN is evaluated with the AOTs derived from the standard Dark Target and Deep Blue algorithms of the Aqua-MODIS products over northern Africa and a set of sun photometer measurements located at Banizoumbou, Cinzana, DMN_ Maine_ Soroa (hereafter Soroa), Mbour and Cape Verde. In order to validate the ALADIN vertical distribution of aerosols, we use the mean extinction profiles derived from CALIOP.

The paper is organized as follows. A brief description of the ALADIN model and the methodology for analysing the data are given in Sect. 2. The numerical results of dust emission, dry and wet deposition, AOT and extinction coefficients are discussed in Sect. 3. The comparison of the modelled data with Aqua-MODIS products, AERONET data sets, surface concentration observation and CALIOP observation is presented in Sect. 4. Section 5 is devoted to the concluding discussion.

\section{Tools and methods}

\subsection{Model description and dust transport}

The spectral hydrostatic atmospheric numerical prediction model ALADIN is used in this study. ALADIN is a primitive equations model using a two-time-level semi-Lagrangian semi-implicit time integration scheme and a digital filter initialization (Bubnová et al., 1995; Radnóti, 1995). The at- mospheric prognostic variables of the model comprise the wind horizontal components, temperature and specific humidity fields of water vapour and the four types of hydrometeors (cloud droplets, ice crystals, rain and snow), as well as the turbulent kinetic energy. The influence of subgrid physical processes (radiation, microphysics, turbulence, convection, gravity waves, surface processes) on the evolution of the model's prognostic variables is represented with physical parameterizations. The radiative transfer in the atmosphere (gaseous, clouds, ozone and aerosols) and at the surface is described using the RRTM scheme (rapid radiative transfer model) for longwave radiation (Mlawer et al., 1997) and the six-band Fouquart-Morcrette scheme for shortwave radiation (Fouquart and Bonnel, 1980; Morcrette, 1991). Several phenomena linked to the subgrid orography, such as gravity waves, their reflection and trapping, as well as upstream blocking, are taken into account (Catry et al., 2008). The transport in the atmospheric boundary layer is represented with a diffusion scheme based on prognostic turbulent kinetic energy (Cuxart et al., 2000), using the Bougeault and Lacarrère (1989) mixing length, and on a mass flux shallow convection scheme using a CAPE (convective available potential energy) closure (Bechtold et al., 2001). Deep convection is represented with a mass flux scheme based on a moisture convergence closure (Bougeault, 1985). A statistical cloud scheme (Smith, 1990; Bouteloup et al., 2005) is used for the representation of stratiform clouds. Microphysical processes such as auto-conversion, collection, evaporation, sublimation, melting and sedimentation are represented following the parameterization of Lopez (2002). Surface processes are calculated using the externalized surface scheme SURFEX (SURFace EXternalisée) (Masson et al., 2013) which includes the Interaction Soil Biosphere Atmosphere (ISBA) scheme (Noilhan and Planton, 1989). This model configuration is very close to the operational configurations used at Météo-France - in ALADIN overseas applications, for instance - and in about 16 National Weather Service members of the ALADIN consortium.

Dust transport and optical properties are calculated using the three-moment Organic Inorganic Log-normal Aerosol Model (ORILAM) (Tulet et al., 2005). ORILAM predicts the evolution of the aerosol composition, along with the number, mean radius and standard deviation of the aerosol distribution (Binkowski and Roselle, 2003). The method of calculation of aerosol optical properties is described in Grini et al. (2006). The refraction indexes used in our work have been calculated following a table of interpolation proposed by Grini et al. (2006). The dust optical properties are calculated from these new indexes as a function of the lognormal parameter upon the AMMA (African Monsoon Multidisciplinary Analyses) size distribution (Tulet et al., 2008). ORILAM has been evaluated in several papers for the western African region. Crumeyrolle et al. (2008, 2011) presented a thorough description of the size distribution for the AMMA campaign. Mallet et al. (2009) studied the evolution of the 
asymmetry factor $(g)$ and the single-scattering albedo (SSA) for the dust storm event of March 2006 and studied the radiative balance over western Africa. Such specific studies, however, only can be carried out for particular situations. Dry deposition is calculated according to Seinfeld and Pandis (1997), using the resistance concept from Wesely (1989). Sedimentation of aerosols is driven by the gravitational velocity (Tulet et al., 2005).

The wet removal of dust aerosols is calculated using the SCAVenging submodel (Tost et al., 2006; Tulet et al., 2010). The dry deposition and sedimentation are driven by the Brownian diffusivity (Tulet et al., 2005).

\subsection{Dust emission model}

The dust fluxes are calculated using the Dust Entrainment And Deposition (DEAD) model (Zender et al., 2003). The physical parameterizations in the DEAD scheme are based on the Marticorena and Bergametti (1995) scheme, in which dust is calculated as a function of saltation and sandblasting. The dust mobilization starts when the wind friction velocity over an erodible surface exceeds a threshold value (Bagnold, 1941; Chepil, 1951). This threshold friction velocity is controlled primarily by surface and soil conditions (e.g. surface roughness and soil size distribution).

DEAD was implemented in the ISBA scheme embedded in SURFEX (Grini et al., 2006). Recently this emission parameterization has been improved by Mokhtari et al. (2012) in order to better account for the soil aggregate distribution.

The erodible soil fraction is related to bare and rock soil. These surface types are derived from the global data set of land surface ECOCLIMAP at a $1 \mathrm{~km}$ resolution, which combines the global land cover maps at a $1 / 120^{\circ}$ resolution and satellite information (Masson et al., 2003). Two hundred and fifteen ecosystems were obtained by combining existing land cover and climate maps, in addition to using advanced very high-resolution radiometer (AVHRR) satellite data. The ECOCLIMAP database is designed in compliance with the SURFEX "tile" approach: each grid box is composed of four adjacent surfaces for nature (ISBA vegetation classes), urban areas (TEB - Town Energy Balance - model), sea, or ocean and lake. The mass fractions of clay, sand and silt are provided from the global $10 \mathrm{~km}$ FAO soil data sets. Soil texture is classified following the USDA (1999) (United States Department of Agriculture) textural classification with 12 basic textural definitions. Soil aggregate size distributions are defined for each texture.

For the size distribution of the emitted dust, we adopted the proposal of Crumeyrolle et al. (2011) based on the measurements taken during the AMMA Special Observing Period (SOP) of June 2006. The different parameters related to this distribution are shown in Table 1.
Table 1. Log-normal parameters of the AMMA size distribution used in DEAD coupled with SURFEX.

\begin{tabular}{llll}
\hline & Mode 1 & Mode 2 & Mode 3 \\
\hline Number fraction $(\%)$ & 97.52 & 1.95 & 0.52 \\
Mass fraction $(\%)$ & 0.08 & 0.92 & 99 \\
Geometric standard deviation & 1.75 & 1.76 & 1.7 \\
Number median diameter $(\mu \mathrm{m})$ & 0.078 & 0.64 & 5.0 \\
Mass median diameter $(\mu \mathrm{m})$ & 0.2 & 1.67 & 11.6 \\
\hline
\end{tabular}

\section{$2.3 \quad 2006-2010$ simulations}

The ALADIN model is coupled to the ARPEGE (Action de Recherche Petite Echelle Grande Echelle) global model, which provides the initial and boundary conditions every $3 \mathrm{~h}$. To simulate the 2006-2010 period, successive forecasts of 2 consecutive days $(48 \mathrm{~h})$ are performed. The final term of each simulation is used as the initial condition for the dust concentration of the next simulation. The model simulation has a spin-up period, and in order to start our study with a realistic initial state for dust concentrations, the start date of the numerical simulations is 25 December 2005. However, for the evaluations described in this article, only data from 1 January 2006 through 31 December 2010 are considered. The numerical integrations are performed over a fairly large domain $\left(4^{\circ} \mathrm{S}-40^{\circ} \mathrm{N}, 40^{\circ} \mathrm{W}-50^{\circ} \mathrm{E}\right)$ including all dust emission sources in the Sahara and those of the western part of the Arabian Desert. This choice minimizes the prediction errors in dust concentrations due to lateral coupling, as no dust modelling is included in the coupling global model. Here, care was taken to ensure that no dust emission zone was present outside and near the limited area domain. The postprocessing domain was intentionally decreased in order to facilitate the exploitation of results; it extends from $2^{\circ} \mathrm{N}$ to $38^{\circ} \mathrm{N}$ and from $39^{\circ} \mathrm{W}$ to $45^{\circ} \mathrm{E}$. The horizontal resolution is $20 \mathrm{~km} \times 20 \mathrm{~km}$ with 60 hybrid vertical levels from the surface to $67 \mathrm{~km}$. The time step is $600 \mathrm{~s}$. In this paper, we restrict the analysis to the extinction coefficient and its vertical integration (AOT) for comparison with the observations available for the 2006-2010 period.

\subsection{Data set}

\subsubsection{Ground-based measurement}

In this study we use the AERONET AOT product (level 2) and the $\mathrm{PM}_{10}$ measured dust mass concentration (particulate matter concentration, particles with diameter of $10 \mu \mathrm{m}$ or less) in order to evaluate the model-simulated AOT and the surface dust concentration, respectively, from 2006 to 2010.

AERONET (http://aeronet.gsfc.nasa.gov/) is a federation of ground-based remote-sensing instruments measuring aerosol and its characteristics (Holben et al., 1998). The AERONET sun photometers directly measure aerosol optical thickness at seven wavelengths (approximately 0.340, 


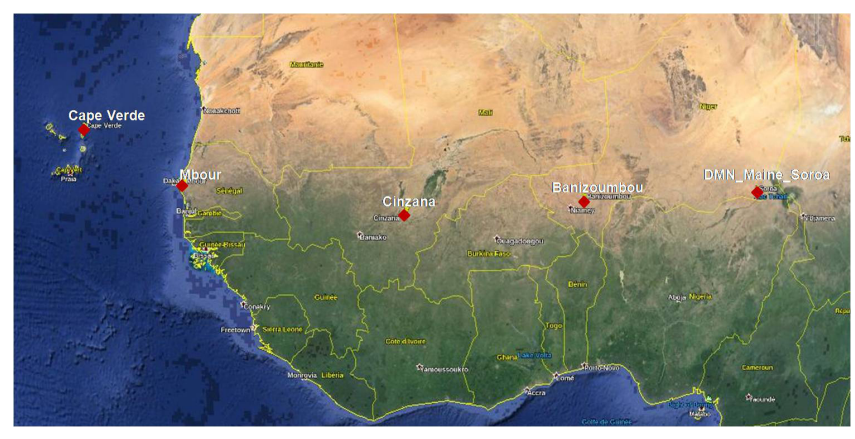

Figure 1. Location of the five AERONET sites used in this study to evaluate the ALADIN-simulated AOT over western Africa: Banizoumbou (Niger), Cinzana (Mali), Soroa (Niger), Mbour (Senegal) and Cape Verde.

$0.380,0.440,0.500,0.675,0.870$ and $1.02 \mu \mathrm{m})$ with an estimated uncertainty of $0.01-0.02$ (Holben et al., 2001). In the model, the AOT is simulated at $0.55 \mu \mathrm{m}$, and it is therefore compared to the AOT measured at the nearest wavelength, 0.440 or $0.675 \mu \mathrm{m}$. Following Schmechtig et al. (2011) the AOT measured over Banizoumbou, Cinzana and Mbour, at the wavelengths 0.44 and $0.675 \mu \mathrm{m}$, are significantly correlated $\left(r^{2}=0.99\right)$, with slopes ranging from 1.04 in Cinzana to 1.06 in Mbour. Thus, in our study, we used the AOT measured at $0.44 \mu \mathrm{m}$ over the five AERONET sites located in western Africa at Banizoumbou (Niger), Cinzana (Mali), Soroa (Niger), Mbour (Senegal) and Cape Verde (Fig. 1). We note that the AOT measurements are only possible during the day since they are based on measuring the solar radiation attenuation. This characteristic may affect the results of the intercomparison if a dust storm event occurs at night-time.

The three stations composing the "Sahelian dust transect" (SDT) (Marticorena et al., 2010) located in the Sahelian region at Banizoumbou, Cinzana and Mbour are used to validate the surface dust concentration simulated by ALADIN. The SDT provides a continuous monitoring of the atmospheric concentrations of $\mathrm{PM}_{10}$ with a 5-min time step, using a tapered element oscillating microbalance (TEOM 1400A from Thermo Scientific) equipped with a $\mathrm{PM}_{10}$ inlet. $\mathrm{PM}_{10}$ measurements refer to particulate matter which passes through a size-selective inlet with a $50 \%$ efficiency cutoff at $10 \mu \mathrm{m}$ aerodynamic diameter (Marticorena et al., 2010). In terms of sensitivity, the detection limit of the instrument is about $0.06 \mu \mathrm{g} \mathrm{m}^{-3}$ for a 1-hour sampling time.

\subsubsection{Satellite data}

The Aqua-MODIS product (Tanré et al., 1997; Levy et al., 2007) was used to evaluate the AOTs simulated by ALADIN. This instrument is a multispectral radiometer, designed to retrieve aerosol microphysical and optical properties over ocean and land. Two products of Aqua-MODIS are considered in this study: the MODIS Dark Target (DT) and the
MODIS Deep Blue (DB) algorithms (Hsu et al., 2004). The MODIS DT algorithm over land is not designed to retrieve aerosol over bright surfaces, such as the Sahara, due to the large values of surface reflectivity (Remer et al., 2005; Shi et al., 2013). This problem leads to large spatial gaps in the aerosol optical thickness recorded in desert regions, although these regions are affected by some of the largest aerosol loadings worldwide. However, the DB algorithm takes advantage of this surface phenomenology by performing aerosol retrievals in the visible blue spectrum (such as the $0.47 \mu \mathrm{m}$ spectral channel in MODIS) and by utilizing the selected aerosol model in the inversion to generate the AOT (Hsu et al., 2004, 2006; Shi et al., 2013). Thus, a combination between these two products is made to complete the AOT database for the whole of northern Africa (ocean and land).

Over bright arid regions, only DB data are available, offering no alternative choice. Conversely, in the areas with dense vegetation and ocean, only DT data are available and are therefore used in our study in these regions. In addition, we have transition areas with low vegetation, such as the Sahel $\left(10-15^{\circ} \mathrm{N}\right)$. For these areas, both the DB and DT products are available. The DT product for the semi-arid regions tends, however, to be biased and to underestimate values (Levy et al., 2010). For example, the difference between DB and DT estimated for the transition regions can exceed 0.3. For this reason we chose the DB product for the transition regions. Recently, Levy et al. (2013) proposed another solution for the transition regions, namely to merge the two products and create a combined AOD (aerosol optical depth) product. Levy et al. (2013) used the normalized difference vegetation index (NDVI) to identify these regions. Unfortunately, this solution has not yet been validated.

The CALIOP Level 2 Layer $5 \mathrm{~km}$ product was used to evaluate the mean particle vertical distributions simulated by ALADIN over northern Africa. The CALIOP instrument (Winker et al., 2007) was launched in 2006 on the Cloud-Aerosol Lidar and Pathfinder Satellite Observations (CALIPSO) spacecraft and has now provided over 8 years of nearly continuous global measurements of aerosols and clouds with high vertical and spatial resolution at two wavelengths (532 and $1064 \mathrm{~nm}$ ) (Rogers et al., 2014). As part of the "A-train" multisatellite constellation, CALIPSO follows a $705 \mathrm{~km}$ sun-synchronous polar orbit, with an equatorcrossing time of about 13:30, local solar time (Stephens et al., 2002). The orbit repeats the same ground track every 16 days. The vertical distribution of aerosols, provided by lidar, is important for radiative forcing (e.g. Satheesh, 2002), air quality studies (e.g. Al-Saadi et al., 2005; Engel-Cox et al., 2006) and model validation (Dirksen et al., 2009; Koffi et al., 2012). The CALIOP instrument and its initial performance assessment are described in Winker et al. (2007) and Hunt et al. (2009). 


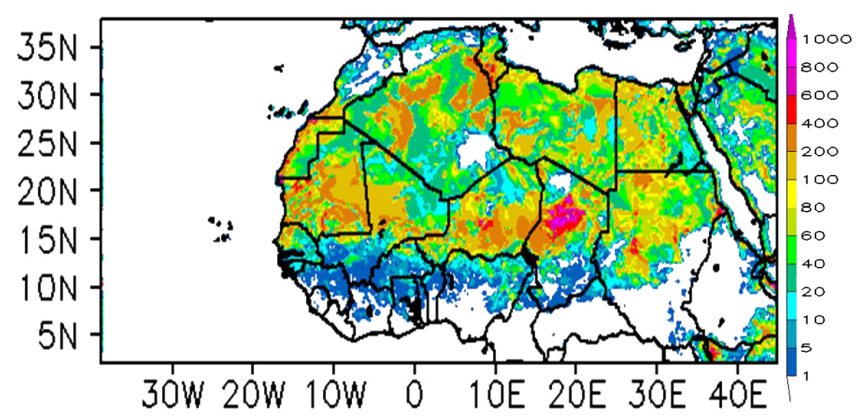

Figure 2. Annual mean dust emissions (in $\mathrm{g} \mathrm{m}^{-2}$ ) over northern Africa averaged for the 2006-2010 period simulated by ALADIN.

\section{Results}

\subsection{Dust emissions}

\subsubsection{Annual dust emissions and interannual variability}

Figure 2 shows the annual mean dust emissions over the Sahara averaged from 2006 to 2010 and simulated by ALADIN coupled on-line with the ORILAM aerosol scheme and the DEAD version of Mokhtari et al. (2012). The major dust sources are located over the Bodélé Depression, with an annual mean dust flux of around $2 \mathrm{~kg} \mathrm{~m}^{-2}$ year $^{-1}$, the centre of Niger (400-600 $\mathrm{g} \mathrm{m}^{-2}$ year $\left.^{-1}\right)$, the oriental and occidental Great Erg in Algeria (200-400 $\mathrm{g} \mathrm{m}^{-2}$ year $^{-1}$ ), the western Sahara coast, the centre of Mauritania and Mali (200$400 \mathrm{~g} \mathrm{~m}^{-2}$ year $^{-1}$ ), the southeastern region of Libya and Sudan (100-200 $\mathrm{g} \mathrm{m}^{-2}$ year $\left.^{-1}\right)$, and along the border between Egypt and Libya (100-200 $\mathrm{g} \mathrm{m}^{-2}$ year $^{-1}$ ).

The averaged annual dust emission over the whole Sahara and for the 5 years of simulation is $878 \mathrm{Tg}_{\text {year }}{ }^{-1}$. Annual dust emissions vary from $843 \mathrm{Tg}$ in 2010 to $924 \mathrm{Tg}$ in 2008 . Table 2 compares the annual mean dust flux obtained in this work with other recent global and regional dust model studies. Important differences in the annual mean dust flux can be observed. The largest value of the annual mean dust flux is simulated by Ginoux et al. (2004) and is $1430 \mathrm{Tg}$ year $^{-1}$, which is twice as large as the value simulated by Marticorena and Bergametti (1996) (665-586 Tg year $\left.^{-1}\right)$. Our estimation lies between those obtained by Ginoux et al. (2004) and by Marticorena and Bergametti (1996) and is in good agreement with the value obtained by d'Almeida (1986), Callot et al. (2000), Laurent et al. (2008) and Zender et al. (2003).

Dust emissions depend on both surface features and soil types, but they also depend on the meteorological conditions (wind and precipitation). These elements are defined differently from one model to another. Global models have a relatively low resolution, and thus misrepresent the surface characteristics (roughness) and the soil types (percentage of clay and percentage of sand). As a consequence, these models tend to overestimate the spread of dust emission areas.
Table 2. Comparison of regional annual mean dust flux between this study and other studies. The unit is $\mathrm{Tg}_{\mathrm{year}}{ }^{-1}$.

\begin{tabular}{llc}
\hline References & \multicolumn{2}{l}{$\begin{array}{l}\text { Annual mean dust emission } \\
\left(\text { Tg year }^{-1} \text { ) }\right.\end{array}$} \\
& 878 in northern Africa \\
\hline This study & $630-710$ & $2006-2010$ \\
d'Almeida (1986) & 1114 & $1979-1982$ \\
Luo et al. (2003) & 1430 & $1981-1996$ \\
Ginoux et al. (2004) & $665-586$ & $1991-1992$ \\
Marticorena et Bergametti (1996) & 760 & $1990-1992$ \\
Callot et al. (2000) & $580-760$ & $1996-2001$ \\
Laurent et al. (2008) & 1018 & $1979-2003$ \\
Tanaka and Chiba (2005) & 693 & $1979-1989$ \\
Werner et al. (2002) & 980 & $1990-1999$ \\
Zender et al. (2003) & & \\
\hline
\end{tabular}

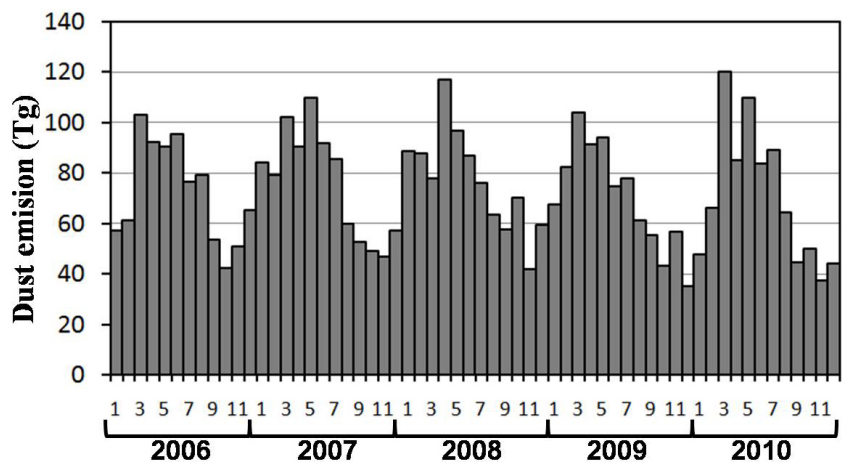

Figure 3. Monthly dust emissions (in Tg) over northern Africa from 2006 to 2010 .

For example, at a $1^{\circ} \times 1^{\circ}$ resolution (medium resolution of global models), an entire area can become a dust emission source when in reality it is not. Eventually, dust emission is overestimated as well. Regional models, due to their higher resolution, provide more details on the emission source areas compared with global models, which then in turn makes it possible to diminish this positive bias.

It is also interesting to note that the three values of dust emission estimated by Zender et al. (2003), Laurent et al. (2008) and Marticorena and Bergametti (1995) and the one of our study are all based on the same dust mobilization scheme of Marticorena and Bergametti (1995). Therefore, a correlation between the estimates of these four studies can be expected. Over the Bodélé Depression $\left(10800 \mathrm{~km}^{2}\right)$, the annual mean dust emission is estimated at $21.4 \mathrm{Tg}^{2}$ year $^{-1}$. Although this region represents only $0.13 \%$ of the Sahara, its contribution is around $2.4 \%$ of the annual mean dust flux of the whole Sahara. This finding is in good agreement with previous studies of this region (Zender et al., 2003). Based on field observations, Todd et al. (2007) suggest that the emission of aerosols minerals from the Bodélé Depression is $1.18 \pm 0.45 \mathrm{Tg} \mathrm{day}^{-1}$ during a substantial dust event.

Figure 3 presents the monthly emissions in Tg from January 2006 to December 2010. This figure shows that the largest monthly emissions are generally obtained in spring. 


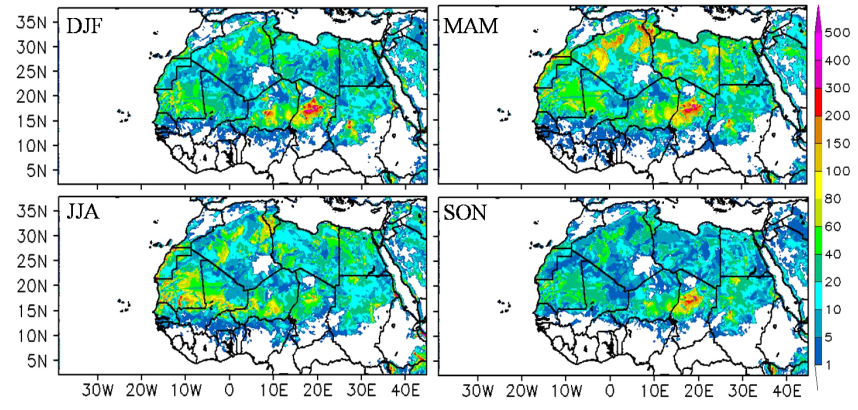

Figure 4. Seasonal mean aerosol dust emissions simulated by ALADIN (in $\mathrm{g} \mathrm{m}^{-2}$ ) over northern Africa averaged for the 2006-2010 period.

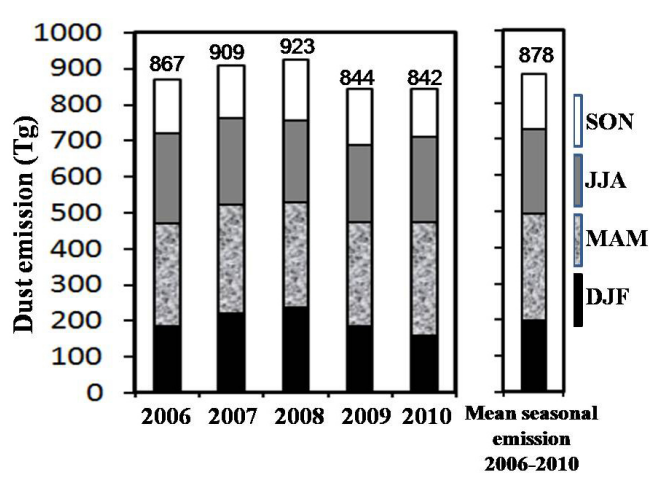

Figure 5. Seasonal mean and interseasonal dust emissions (in $\mathrm{Tg}$ ) simulated by ALADIN over northern Africa from 2006 to 2010. The annual average emission is given at the top of each bar.

During the 5-year simulated period, the maximum $(120 \mathrm{Tg}$ per month) is simulated in March 2010 and the minimum (35 Tg per month) is obtained in December 2009.

\subsubsection{Seasonality of the dust emissions}

Figure 4 shows the seasonal mean dust emissions from 2006 to 2010 . The seasonal cycle is characterized by a maximum of dust emission in spring. All possible dust sources are activated during this season. The minimum dust emissions are simulated in autumn, except over the Bodélé region. In summer, dust emission remains strong in the western Sahara, while it decreases in the eastern Sahara. In winter, dust emission sources are mainly located in the Bodélé Depression and the centre of Niger. These regions are frequently exposed to the harmattan wind during the dry monsoon season, which is a favourable configuration for dust emission. In spring and autumn, dust emission remains significant over the Bodélé Depression, but the dust emission activity decreases in summer. This seasonality is in agreement with the 6-year simulation by Laurent et al. (2008) (1996-2001) and the simulation by Schmechtig et al. (2011) for 2006.

Figure 5 presents the seasonal mean and interseasonal dust emissions over the Sahara during the 5-year period. Our sim- ulations estimate the seasonal mean dust emissions in spring at around $296 \mathrm{Tg}$. In summer, the seasonal emissions remain significant, at about $233 \mathrm{Tg}$. In winter and autumn, our estimations are 196 and $150 \mathrm{Tg}$, respectively. This seasonality reproduces the general pattern of the seasonality simulated by Tanaka and Chiba (2005) for the period 1979-2003 over northern Africa with the global CTM (chemical transport model) (MASINGAR - Model of Aerosol Species IN the Global AtmospheRe) at a resolution of $1.8 \times 1.8^{\circ}$. In contrast, in terms of intensity, the dust emission flux simulated by MASINGAR in spring accounts for almost half of the total emissions in northern Africa $(500 \mathrm{Tg})$. These estimates are higher than those simulated by ALADIN.

In summer, the dust emission flux simulated by MASINGAR is much underestimated compared with the flux estimated by ALADIN. Indeed, the summer season is characterized by significant dust uprising over the Sahel in connection with large convective systems. These systems generate strong gust winds at the leading edge of their cold pools which can lead to "walls of dust" known as "haboob", a sometimes fastmoving and extremely hazardous phenomenon (Knippertz et al. 2012). However, even regional models at a resolution of about $10 \mathrm{~km}$ do not adequately represent these processes, neither in climatological terms nor for weather forecasting (Knippertz et al. 2012).

\subsection{Dry deposition}

The annual dry deposition of mineral dust over northern Africa is another estimated product of the ALADIN integrations. Generally, regions of dry deposition are located near dust emission regions, as most of the emitted dust mass is of the coarse type, which settles quickly. Thus, in the Bodélé Depression, the dust mass subject to dry deposition is at its maximum (400-800 $\mathrm{g} \mathrm{m}^{-2}$ year $^{-1}$ ) and corresponds to around half the annual dust emission. The Ergs located in the centre of Mauritania, Mali and Niger and the Great Eastern and Western Erg in Algeria, western Sudan, southwest of Egypt and Libya come in second, with dry deposition values between 100 and $300 \mathrm{~g} \mathrm{~m}^{-2}$ year $^{-1}$. The mountainous and rocky deserts have a dry deposition ranging from 40 to $100 \mathrm{~g} \mathrm{~m}^{-2}$ year $^{-1}$.

The seasonal mean dry deposition flux is shown in Fig. 6 . The southern boundary of the dry deposition area is modulated by the position of the ITCZ. In winter, the maximum of the seasonal dust deposition flux is located in the Bodéle Depression, with a value reaching $200 \mathrm{~g} \mathrm{~m}^{-2}$. This maximum is a consequence of low-level dust transport during this period. The geographical extension of the dry deposition areas is very large, especially towards the south and the west of the Sahara, which are the main areas of dust transport (Swap et al., 1992; Kaufman et al., 2005). The area of dust deposition of more than $10 \mathrm{~g} \mathrm{~m}^{-2}$ extends southward to about $5^{\circ} \mathrm{N}$ and covers the subtropical Atlantic. In spring, the mean seasonal dust deposition flux is high over the Great Eastern and 

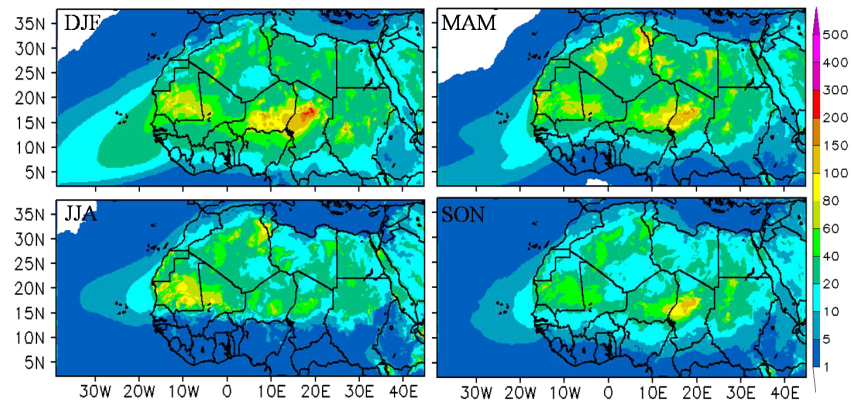

Figure 6. Seasonal mean dry deposition flux simulated by ALADIN (in $\mathrm{g} \mathrm{m}^{-2}$ ) over northern Africa averaged for the 2006-2010 period.
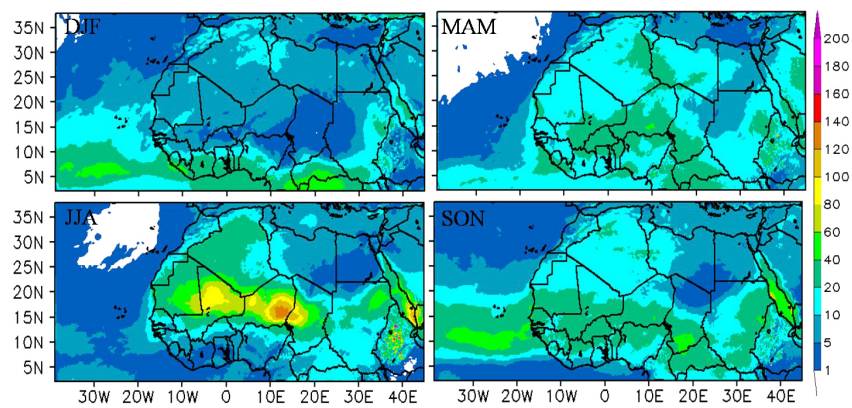

Figure 7. Seasonal mean wet deposition flux simulated by ALADIN (in $\mathrm{g} \mathrm{m}^{-2}$ ) over northern Africa averaged for the 2006-2010 period.

Western Erg in Algeria $\left(150 \mathrm{~g} \mathrm{~m}^{-2}\right)$ but decreases over the Bodélé Depression and Niger. In this season, the southern limit of the extension of the mean seasonal dry deposition area $\left(>10 \mathrm{~g} \mathrm{~m}^{-2}\right)$ is at $10^{\circ} \mathrm{N}$. In summer, this limit is located around $15^{\circ} \mathrm{N}$, in connection with the establishment of the West African monsoon and the northward migration of the ITCZ. This season is characterized by high precipitation over western Africa, which is very efficient at suppressing dust emission and generates significant washout. In autumn, in conjunction with the decrease in the dust emission activity over the Sahara, the mean seasonal dust deposition decreases, except in the Bodélé Depression.

\subsection{Wet deposition}

In this section, we show that the use of a 3-D NWP model such as ALADIN significantly improves the climatology of wet deposition of dust aerosols. Indeed, the model provides a representation of large-scale and mesoscale precipitating processes, with a spatial and temporal resolution and operational-like calibration of the schemes, which provides insight into regional and seasonal aspects of wet deposition.

Figure 7 presents the mean seasonal wet deposition flux simulated by ALADIN over northern Africa, averaged for the 2006-2010 period. The location of wet deposition areas depends mainly on the distribution of large-scale and convec-
Table 3. Mean dust wet deposition.

\begin{tabular}{ll}
\hline Models & $\begin{array}{l}\text { Wet deposition } \\
\text { for } 2006 \text { in } \\
\mathrm{g} \mathrm{m}^{-2} \text { year }^{-1}\end{array}$ \\
\hline BSC-DREAM8b & 0.46 \\
GOCART-v4Ed.A2.CTRL & 9.653 \\
GISS-modelE.A2.CTRL & 8.301 \\
TM5-V3.A2.CTRL & 4.673 \\
This study & 21.36 \\
\hline
\end{tabular}

tive precipitations and the direction of dust plume transport. In winter, during the dry West African monsoon season, the mean wet deposition fluxes simulated by ALADIN do not exceed $10 \mathrm{~g} \mathrm{~m}^{-2}$ in the Sahara and Sahelian regions. In contrast, wet deposition is very active $\left(20\right.$ to $\left.60 \mathrm{~g} \mathrm{~m}^{-2}\right)$ in the band from 0 to $10^{\circ} \mathrm{N}$ over the Gulf of Guinea and the Atlantic Ocean. In spring, the highest mean wet deposition flux is observed over the south of Niger, with values exceeding $40 \mathrm{~g} \mathrm{~m}^{-2}$. Summer is the season of the wet African monsoon, characterized by large convective systems over the Sahelian regions. These systems play a key role in the wet deposition of mineral dust aerosols. Since these convective systems produce aerosols in the gust front, the associated aerosols are to a large extent washed out by precipitation (Flamant et al., 2007; Tulet et al., 2010). As a consequence, in our simulation, ALADIN simulates the maximum wet deposition in the band from 15 to $20^{\circ} \mathrm{N}$. This band corresponds to western Chad, central Niger, Mali and Mauritania, with average values of $60-140 \mathrm{~g} \mathrm{~m}^{-2}$. Autumn is characterized by the turning of the African monsoon and the southward displacement of the ITCZ, in conjunction with a decrease in precipitation and wet deposition over the Sahelian region. We note that, beyond $10^{\circ} \mathrm{N}$, wet deposition processes are more efficient than dry deposition.

The intercomparison of dust wet deposition simulated by ALADIN for the year 2006 with models used in the AEROCOM (Aerosol Comparisons between Observations and Models) and SDS-WAS programs (BSCDREAM8b, GOCART (Global Ozone Chemistry Aerosol Radiation and Transport)-v4Ed.A2.CTRL, GISS (Goddard Institute for Space Studies)-modelE.A2.CTRL and TM5 (tracer model, version 5)-V3.A2.CTRL, http://aerocom.met. no/cgi-bin/aerocom/surfobs_annualrs.pl) for the same period is given by the Table 3 . The results show that the mean wet deposition estimated by ALADIN is much higher than that estimated by AERCOM models. As discussed for the seasonal wet deposition, the major part of the wet deposition takes place during the wet season of the African monsoon.

In terms of spatial distribution, the ALADIN model performs better for the estimation of the dust wet deposition associated with convective systems in the Sahelian regions. For example, the estimates of the BSC-DREAM8b model do 


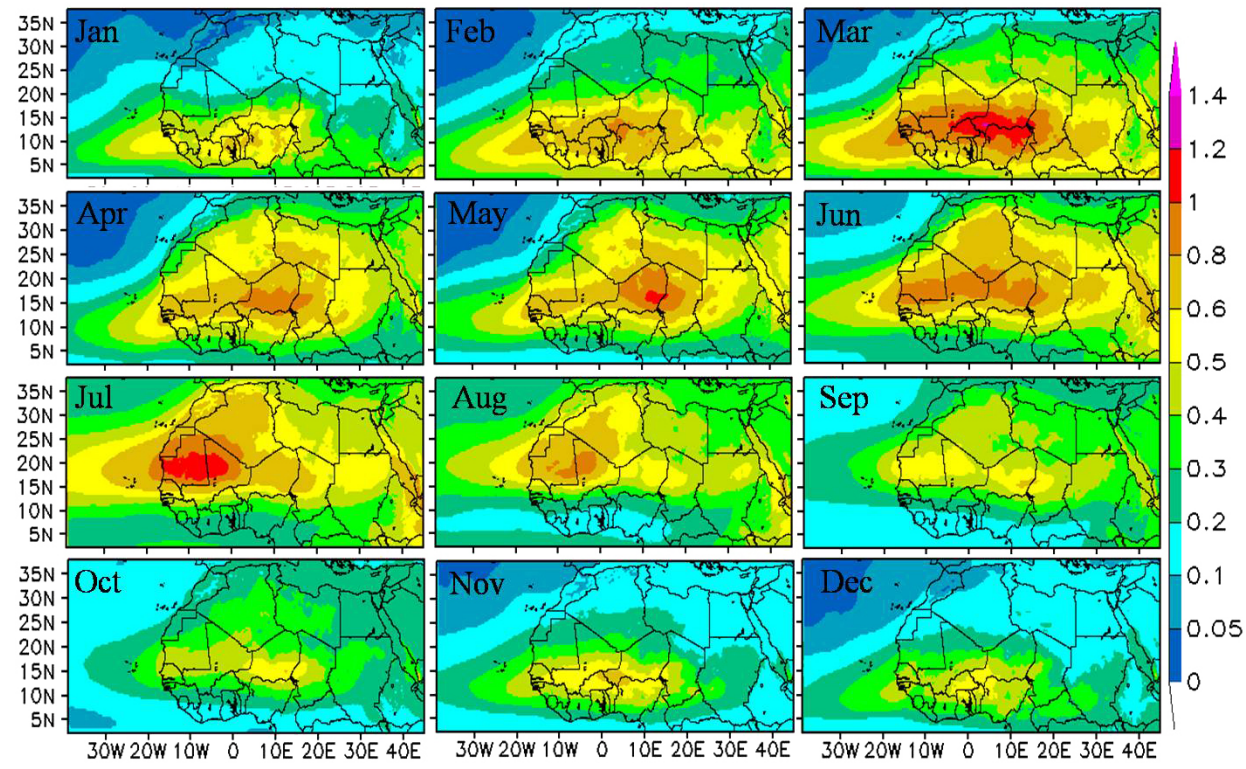

Figure 8. Monthly aerosol optical thickness (AOT) simulated by ALADIN averaged over the 2006-2010 period.

not exceed $0.2 \mathrm{~g} \mathrm{~m}^{-2}$ year $^{-1}$ for the Sahel and the western African region. Those simulated by TM5-V3.A2.CTRL are less than $5 \mathrm{~g} \mathrm{~m}^{-2}$ year $^{-1}$, and those obtained by GOCARTv4Ed.A2.CTRL and GISS-modelE.A2.CTRL varied in the range of $20-50 \mathrm{~g} \mathrm{~m}^{-2}$ year $^{-1}$. The fact that some part of the total precipitation of ALADIN is resolved can explain the fact that the wet deposition processes in ALADIN are found to be more efficient than in some global models.

\subsection{Monthly variation in aerosol optical thickness}

Figure 8 shows the monthly aerosol optical thickness averaged from 2006 through to 2010 over northern Africa. The monthly variation is characterized by AOT two maxima exceeding 1.2. The first maximum is simulated in March and is located over the Sahelian region in western Africa. This maximum is correlated with the high dust emissions observed in the Bodélé Depression and the centre of Niger. The second maximum is simulated in July and is located over Mauritania and Mali. This maximum is related to the appearance of the heat low in these regions and to the northward movement of the ITCZ in July. Low AOT values are registered in autumn. This season is characterized by low dust emission activity, and the simulated AOTs do not exceed 0.8. Over the southern part of the Mediterranean Sea (Libyan and Egyptian coast), the AOTs due to dust are significant in spring and summer, with a monthly peak of 0.5 in July. Note that, using both satellites and a regional chemistry model, Nabat et al. (2013) found, for the 1979-2009 period, an AOT value of 0.3 for these regions with a peak in June.

In terms of extension, the spatial distribution of AOTs follows the preferred dust transport direction in northern Africa. The large AOT values (0.6 to 1.2) are located in the south of the domain $5^{\circ} \mathrm{N}-20^{\circ} \mathrm{N}$, from December to March. In contrast, beyond $20^{\circ} \mathrm{N}$, the AOTs do not exceed 0.4 for this period. From April to August, the regions with large AOTs (0.6 to 1.2) follow the northward displacement of the ITCZ. Accordingly, in the ALADIN simulation, these regions extend fairly far north $\left(>10^{\circ} \mathrm{N}\right)$, covering major parts of the western Sahara and the Sahelian regions. In addition, a band of high AOT (0.4 to 0.8), associated with the westward transport of dust aerosols towards the Atlantic Ocean, is simulated between $10^{\circ} \mathrm{N}$ and $25^{\circ} \mathrm{N}$. From September to November the dust aerosol activity decreases and the regions of high AOT (0.6 to 0.8 ) are only located in parts of the Sahelian region and the Bodélé Depression. The spatial distribution of AOT simulated by ALADIN is well correlated with the monthly average of the AAI derived from TOMS data, found by Engelstaedter et al. (2006) for the 1980-1992 period, especially for May, June, July and August. However, noticeable differences are observed between AOT and AAI fields in winter, especially for the month of March, which corresponds to an AAI minimum and an AOT maximum.

\subsection{Monthly variation in extinction coefficients}

The vertical distribution of aerosols in the troposphere is important for assessing their effects on climate and is a key parameter in the objective evaluation of radiative forcing ( $\mathrm{Li}$ et al., 2007; Kinne et al., 2006; Zhu et al., 2007). Meloni et al. (2005) found that the intensity of shortwave radiative forcing at the top of the atmosphere is strongly dependent on the vertical distribution of aerosols. In this paper, we show the monthly variation in the vertical distribution of mineral dust from the surface to $10 \mathrm{~km}$ of altitude. In order to emphasize this distribution for low altitudes, we chose the log- 


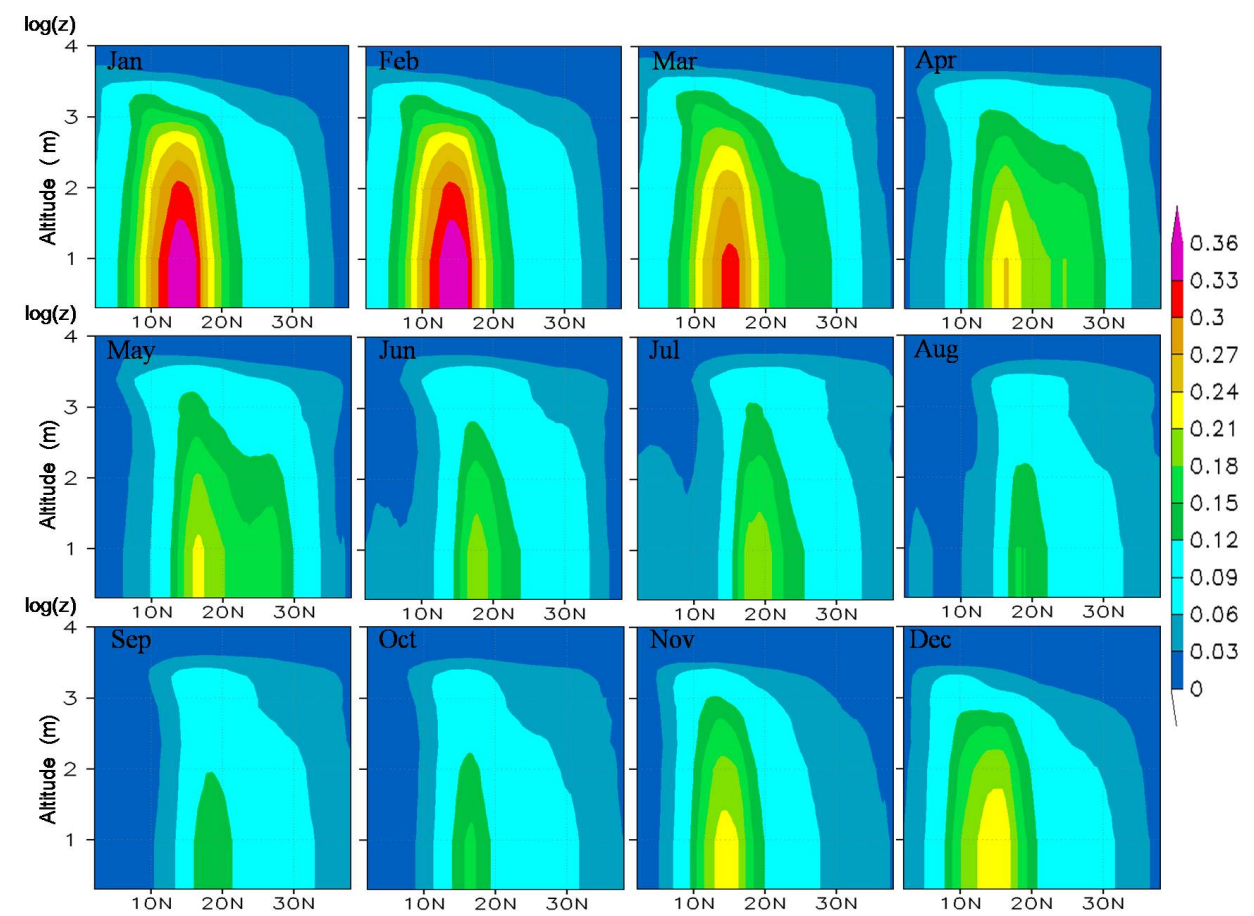

Figure 9. Monthly vertical cross section $\left(30^{\circ} \mathrm{W}-40^{\circ} \mathrm{E}\right)$ of extinction coefficients (in $\mathrm{km}^{-1}$ ) simulated by ALADIN averaged from 2006 to 2010 over northern Africa.

arithmic scale for the vertical coordinate. The vertical distribution is represented by the vertical cross section of the extinction coefficients averaged longitudinally from $30^{\circ} \mathrm{W}$ to $40^{\circ} \mathrm{E}$ and from 2006 to 2010 (Fig. 9). The maximum of the extinction coefficient is simulated in January and February and reaches $0.36 \mathrm{~km}^{-1}$. This maximum is located in the lowest layer $(<100 \mathrm{~m})$ between 12 and $17^{\circ} \mathrm{N}$, with a vertical inclination toward the south. The southward inclination observed above $1.5 \mathrm{~km}$ of altitude is due to the location of dust aerosols in the Saharan atmospheric layer (SAL) and their transport by the Harmattan wind above the monsoon flux. This vertical structure is mainly observed in winter during the dry West African monsoon. In this season, a strong gradient of extinction coefficients can be observed at the surface around the ITCZ $\left(5-15^{\circ} \mathrm{N}\right)$, with values varying from 0.09 to $0.36 \mathrm{~km}^{-1}$. In altitude, over the monsoon flux $(1.5$ to $3 \mathrm{~km})$, the extinction coefficients are relatively large $\left(0.09 \mathrm{~km}^{-1}\right)$. The annual minimum of the maximum values of extinction are simulated in September and October and do not exceed $0.12 \mathrm{~km}^{-1}$, with a vertical extension limited to below $4 \mathrm{~km}$. In summer, the onset of the West African monsoon and the northward movement of the ITCZ confine the transport of dust to the south. Instead, dust is mixed and transported vertically by convective systems to high altitudes $(6 \mathrm{~km})$. At the surface, the limit of the southern extension of the extinction coefficient $\left(>0.06 \mathrm{~km}^{-1}\right)$ marks the position of the ITCZ. This limit varies between $2^{\circ} \mathrm{N}$ in winter and $15^{\circ} \mathrm{N}$ in summer.

\section{Comparison and evaluation}

\subsection{Comparison of simulation outputs to Aqua-MODIS observations}

Figure 10 shows the Level-3 monthly AOTs derived from the combination of the Dark Target and Deep Blue products (MYD08_D3.051, MODIS-Aqua Ver. 5.1) at a $1 \times 1^{\circ}$ resolution averaged from 2006 to 2010. The MODIS data show important dust activity from January to August. We observe high-AOT values, in excess of 0.5 , over large portions of northern Africa. The most important dust activity is observed in March. Two maxima exceeding 1 can be identified for this month. A primary maximum is located over the Gulf of Guinea, Nigeria, Benin and the region of Ouagadougou (south-west of Niger). This maximum is associated with the southward dust transport, which is very significant in this season. The secondary maximum is located in the Bodélé Depression in Chad and is therefore collocated with the main area of dust emission.

Compared with the simulated AOTs (Fig. 7), ALADIN reproduces the monthly horizontal distribution of AOT well. However, the model gives larger AOT values than MODIS, especially in the Sahelian region, central Mauritania and Mali, from March to July. Still, in the Bodélé Depression, the maximum AOT ( 0.8 to 1 ) simulated by ALADIN in March is underestimated compared with that given by MODIS (1.2 to 1.4) for the same month. Note that for this region, Kocha 

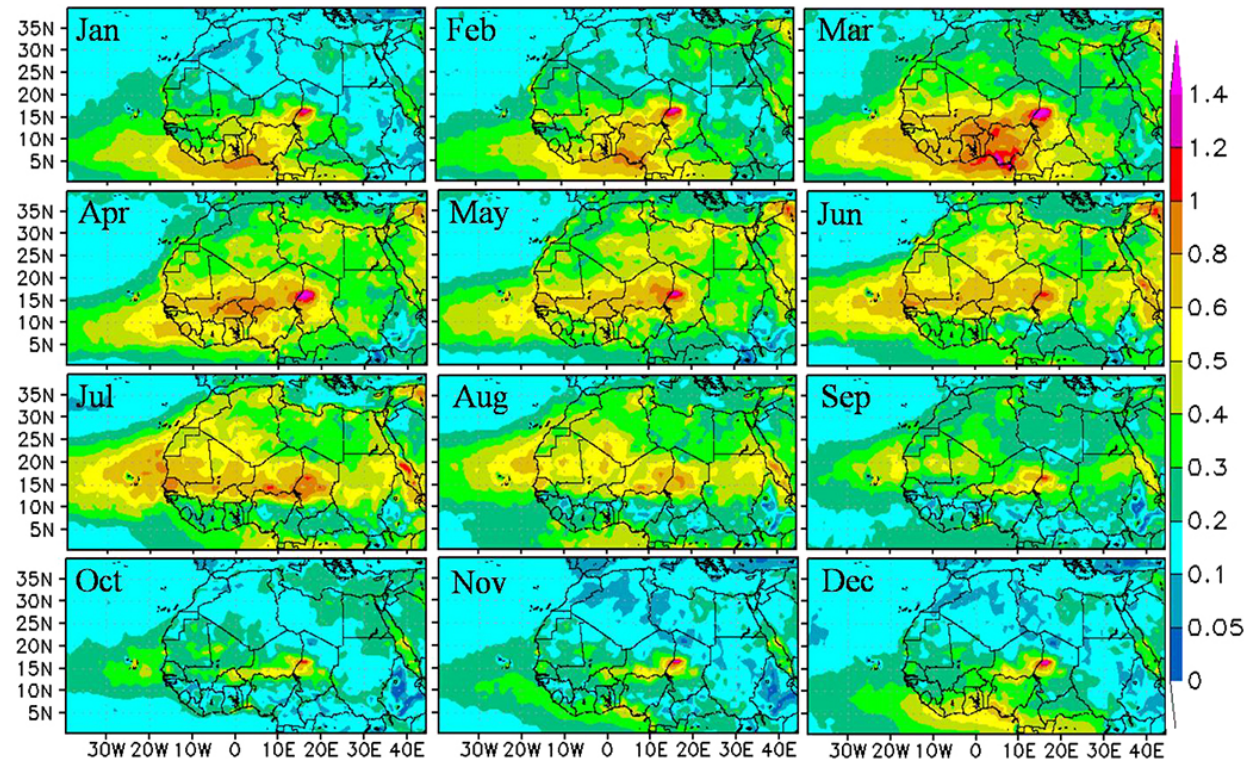

Figure 10. Monthly aerosol optical thickness derived from the combination of the standard and Deep Blue products applied to Aqua-MODIS data over northern Africa for the 2006-2010 period.

et al. (2013) give an estimate of the AOT bias of MODIS of about +0.1 . Indeed, Aqua and Terra observe this region between 09:30 and 12:30 UTC and capture the maximum of dust concentration. Therefore, Kocha et al. (2013) conclude that the overestimation of the AOT values in the MODIS monthly mean product due to the poor representation of the diurnal cycle of dust is of the order of 0.1, i.e. $17 \%$.

Over the Gulf of Guinea, ALADIN underestimates the maximum AOT in March, with a value around 0.7, while the observed value from MODIS exceeds 1 . Over the Mediterranean Sea, large AOT values (around 0.5) observed by MODIS are obtained in April near the Libyan coast, while the AOT maxima (around 0.5) simulated by ALADIN are obtained in July and August, located in the eastern Mediterranean. Over the Atlantic Ocean, good agreement is obtained between ALADIN simulations and MODIS observations in terms of both horizontal distribution and maximum AOT values.

\subsection{Comparison with AERONET measurements}

The AOTs simulated by ALADIN have also been compared with the AERONET observations available in the AMMA database and the MODIS products. Figures 11 and 12 show, respectively, the average and scatter plot of monthly optical thickness observed by AERONET and MODIS and simulated by ALADIN from 2006 to 2010 over Banizoumbou, Cinzana, Soroa, Mbour and Cape Verde.

The large AOT values ( $>0.6)$ measured by AERONET are observed from March to June at the sites of Banizoumbou, Cinzana and Soroa, with a maximum exceeding 0.8 obtained in March at Cinzana, in April at Banizoumbou and in May at

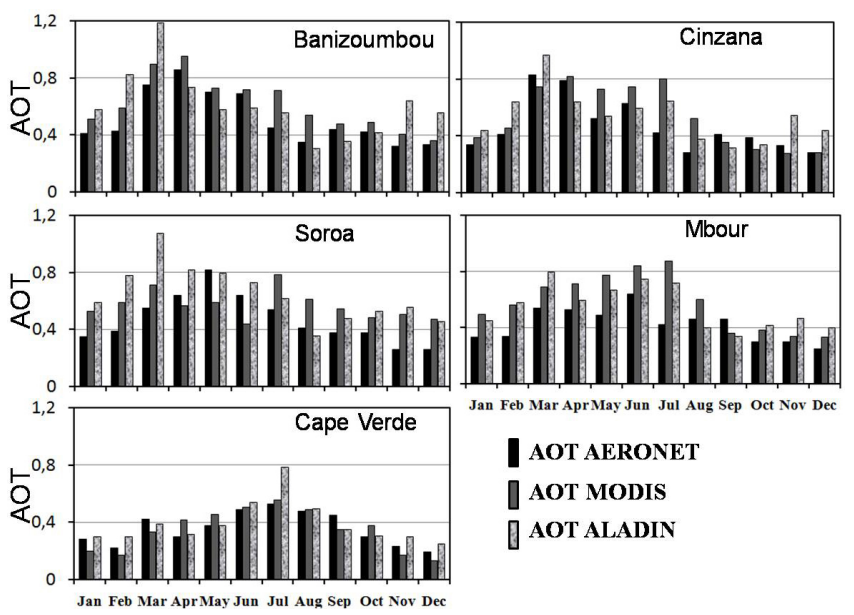

Figure 11. Monthly aerosol optical thickness observed by sun photometer (black) and MODIS (dark grey) and simulated by ALADIN (grey), averaged from 2006 to 2010 over Banizoumbou $\left(13^{\circ} 32^{\prime} 2^{\prime \prime} \mathrm{N}, 2^{\circ} 39^{\prime} 54^{\prime \prime} \mathrm{E}\right)$, Cinzana ( $\left.13^{\circ} 16^{\prime} 40^{\prime \prime} \mathrm{N}, 5^{\circ} 56^{\prime} 2^{\prime \prime} \mathrm{W}\right)$, Soroa $\left(13^{\circ} 13^{\prime} 1^{\prime \prime} \mathrm{N}, \quad 12^{\circ} 1^{\prime} 22^{\prime \prime} \mathrm{E}\right)$, Mbour $\left(14^{\circ} 23^{\prime} 38^{\prime \prime} \mathrm{N}\right.$, $\left.16^{\circ} 57^{\prime} 32^{\prime \prime} \mathrm{W}\right)$ and Cape Verde $\left(16^{\circ} 43^{\prime} 58^{\prime \prime} \mathrm{N}, 22^{\circ} 56^{\prime} 6^{\prime \prime} \mathrm{W}\right)$.

Soroa (Fig. 11). These three stations are located at the same latitude $\left(13^{\circ} \mathrm{N}\right)$, and they mark the southern boundary of the sources of dust emission. They are affected by dust transport associated with the harmattan wind from March to June, which explains the large AOT values in this season. The low AOTs are observed from November to January, with values around 0.35 , corresponding to the low dust emission activity. In August, the AOTs are also low at Banizoumbou, Cinzana and Soroa. For this month, the West African monsoon 


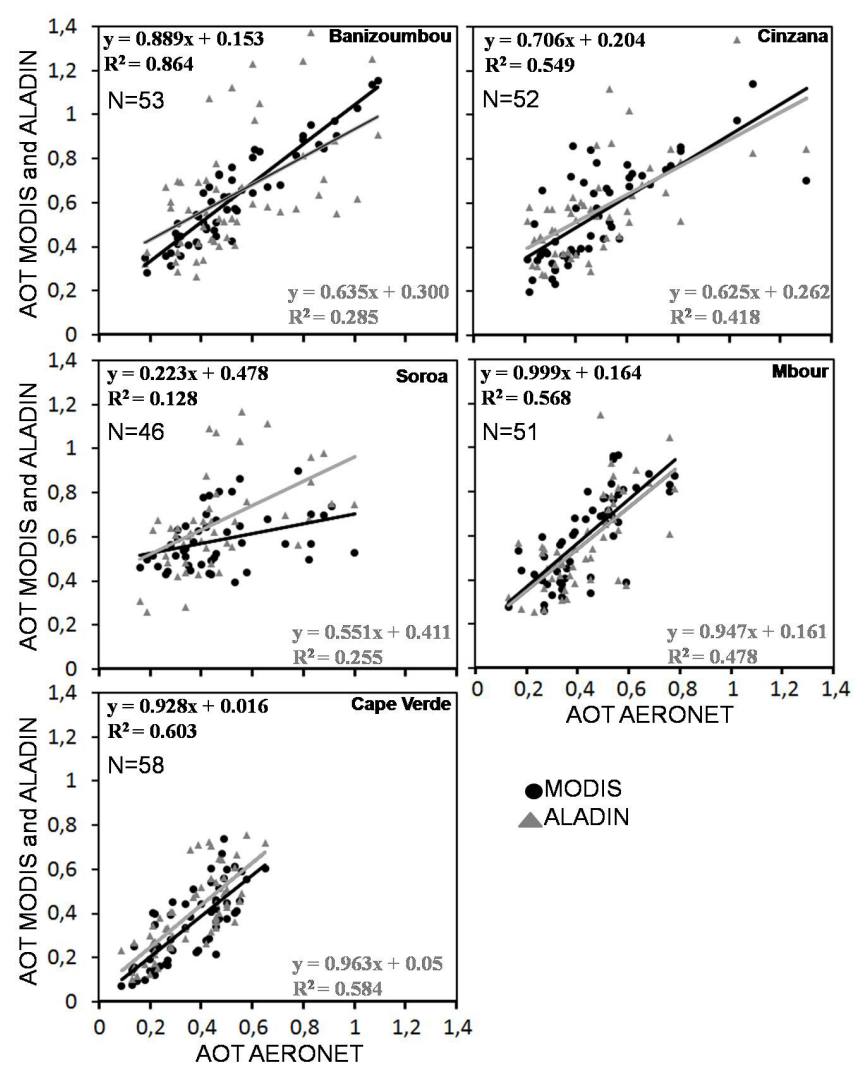

Figure 12. Scatter plot of monthly ALADIN (grey) and MODIS (black) aerosol optical thickness against AERONET measurements over Banizoumbou, Cinzana, Soroa, Mbour and Cape Verde from 2006 to 2010. In abscissa, AERONET measurements; in ordinate, ALADIN and MODIS AOTs. $N$ is the number of averaged monthly data of AOT available from 2006 to 2010. Each marker represents the averaged monthly AOT from 2006 to 2010. $R$ is the correlation coefficient.

is well established and the air circulation is upturned, driving dust aerosol towards the north. A comparison between MODIS and ALADIN shows that the variations in the averaged monthly AOT are well correlated between the two data sets, but there are noticeable differences in terms of quantification. For instance, over Banizoumbou, MODIS observations are slightly larger than AERONET observations for all months, with a maximum of about 1 observed in April. This overestimation is particularly perceptible in the wet monsoon season (July and August). For this site, the MODIS data provide a good correlation coefficient (0.864) (Fig. 12). For ALADIN, the AOT maximum is given in March, with a rather large value of about 1.2. ALADIN overestimates the AOTs from November to March and underestimates them from April to September, except for July. For Banizoumbou, a lower correlation coefficient (0.285) is obtained with ALADIN than with MODIS. This weak correlation is probably due to the resolution of the ALADIN model, which is be- lieved to be too small to provide an appropriate accurate representation of the surface parameters for this region.

Over Cinzana, MODIS gives two AOT maxima reaching 0.8. The first maximum is obtained in April and the second in July. The MODIS AOTs are much larger than the AERONET and ALADIN values from May to August. The correlation coefficient obtained for MODIS for Cinzana is about 0.549 . In contrast, ALADIN simulates the AOT maximum in March $(\sim 1)$ with a correlation coefficient of about 0.418 .

Over Soroa, the maximum AOT $(\sim 0.8)$ is observed by MODIS in July during the wet West African monsoon. MODIS overestimates the AOTs from July to March and underestimates them in May and June compared to AERONET. The correlation coefficient of MODIS is around 0.128. For Soroa, the AOTs simulated by ALADIN are larger than 0.5 from January to July, with a maximum of about 1.1 in March. The correlation coefficient obtained for ALADIN is around 0.255 .

At Mbour, the maximum AOT measured by AERONET is obtained in June and is around 0.7. For this site, MODIS values of AOT are larger than AERONET values from January to August. In July, the AOTs observed by MODIS (0.9) are twice as large as those measured by AERONET. Like MODIS, ALADIN overestimates the AOTs from January to July, with a maximum simulated in March (0.8). For Mbour, the correlation coefficients obtained for MODIS and ALADIN with respect to AERONET are equal to 0.568 and 0.478 , respectively.

Over Cape Verde, the averaged monthly AOTs observed by AERONET and MODIS and simulated by ALADIN are in good agreement, except in July, where ALADIN overestimates the AOTs. The maximum AOTs observed and simulated are obtained in July and are equal to 0.5 for AERONET and MODIS and 0.8 for ALADIN. For this site the correlation coefficients observed for MODIS and ALADIN are 0.603 and 0.584 , respectively.

\subsection{Comparison to surface dust concentration measurements}

In this section we use the measured dust mass concentration $\mathrm{PM}_{10}$ from the SDT (Marticorena et al., 2010) to evaluate the simulated surface dust concentration from 2006 to 2010. $\mathrm{PM}_{10}$ measurements refer to particulate matter which passes through a size-selective inlet with a $50 \%$ efficiency cutoff at $10 \mu \mathrm{m}$ aerodynamic diameter. Therefore, for the simulated concentrations, we consider only the particles smaller than $10 \mu \mathrm{m}$ in order to perform a consistent comparison with the observations. Note that the simulated mass concentration of particles of less than $10 \mu \mathrm{m}$ in diameter represents $40.124 \%$ of the total mass.

The SDT is composed of three stations, namely Banizoumbou, Cinzana and Mbour. Figures 13 and 14 show, respectively, the monthly mean of the daily median value of measured and simulated surface concentrations and the 

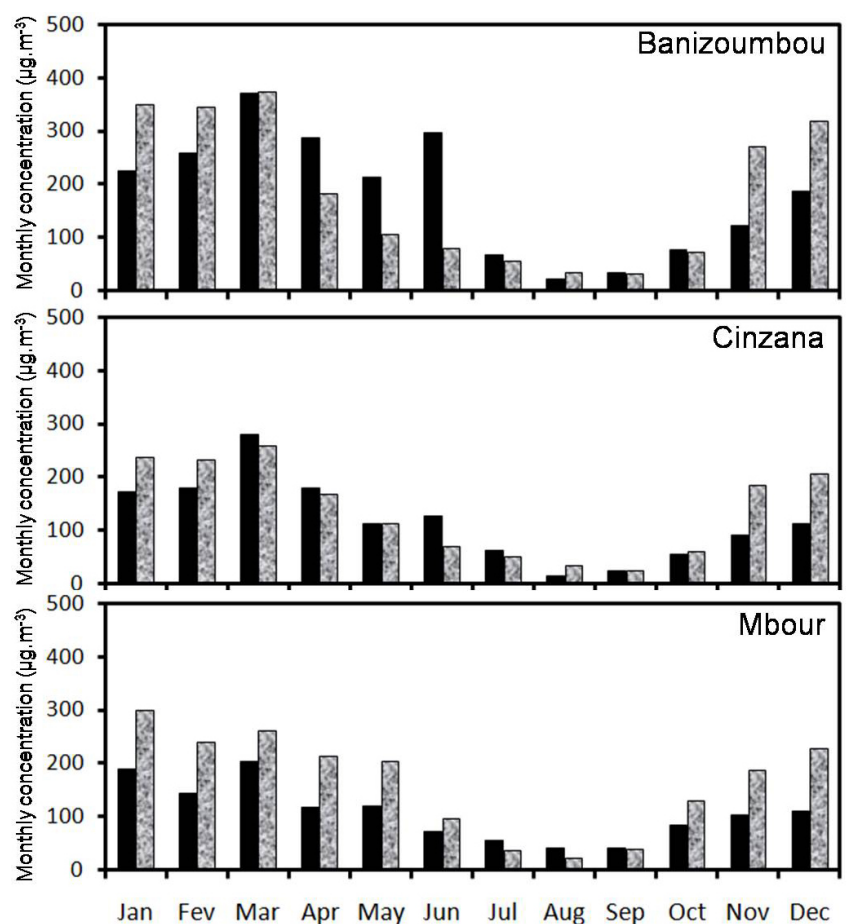

Figure 13. Monthly mean of daily median measured (black) and simulated (grey) surface concentration (in $\mu \mathrm{g} \mathrm{m}^{-3}$ ) in Banizoumbou, Cinzana and Mbour from 2006 to 2010.

scatter plot of monthly ALADIN dust surface concentration against observations over Banizoumbou, Cinzana and Mbour. The analysis of this figure shows that the temporal pattern of simulated and observed concentrations is similar for the Cinzana and Mbour sites, with high concentrations from November to May. In summer, the simulated and observed surface concentrations are low for these two stations. In contrast, noticeable differences are seen from April to June at Banizoumbou. For this site, the simulated surface concentration decreases, while the $\mathrm{PM}_{10}$ concentration remains high. The model underestimations observed during April to June are probably related to local dust uprisings that are not well simulated by the ALADIN model. This underestimation is strong in June, which marks the transition between the dry and the wet season monsoon in western Africa. Recently, a study by Kocha et al. (2013) shows the existence of two important processes responsible for dust uprising in western Africa: (1) the diurnal variation in surface wind speed modulated by the low-level jet occurring after sunrise due to turbulent mixing (Washington et al., 2006), especially in Bodélé Depression; (2) the gust wind associated with the density currents emanating from convective systems occurring in the afternoon. This second phenomenon, generating strong gust winds, can lead to the dust wall known as haboob (Tulet et al., 2010; Knippertz et al., 2012). We also noted a bias for the AOT values in the same period but with a less pronounced intensity than for surface concentration.

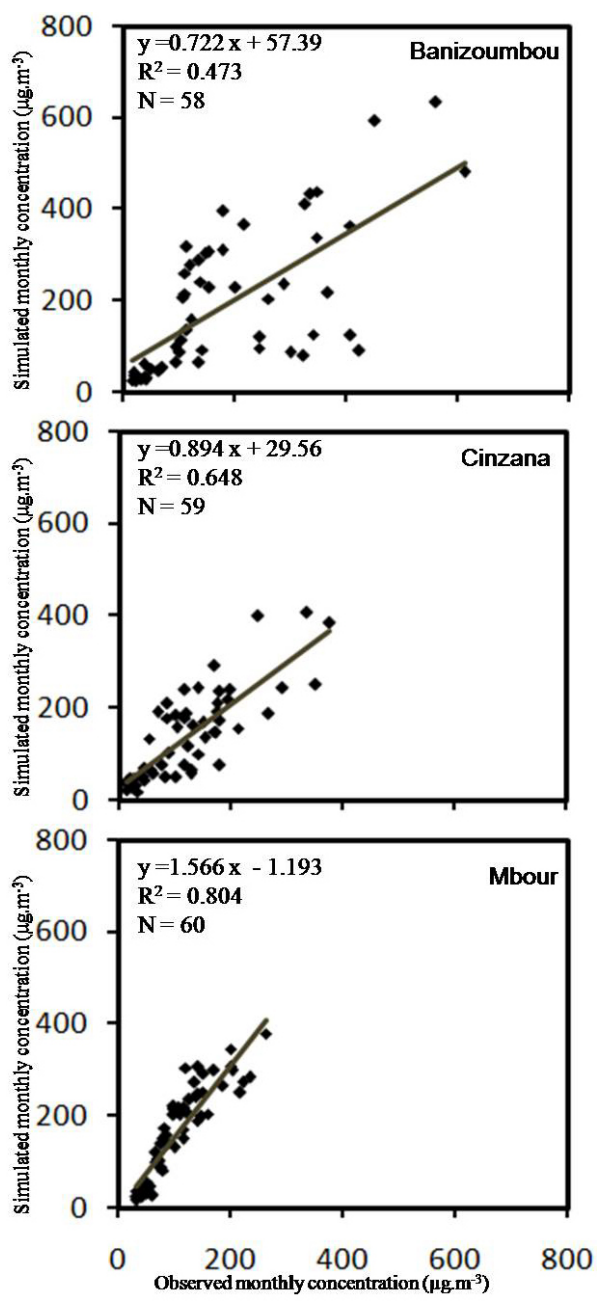

Figure 14. Scatter plot of monthly ALADIN dust surface concentration against observation over Banizoumbou, Cinzana and Mbour from 2006 to $2010 . N$ is the number of averaged monthly surface concentration data available from 2006 to $2010 . R$ is the correlation coefficient.

In terms of intensity, ALADIN overestimates the monthly surface concentration over Banizoumbou from November to February. Nevertheless, it underestimates it from April to July. ALADIN simulates the maximum concentration in March $\left(373 \mu \mathrm{g} \mathrm{m}^{-3}\right)$, which is in good agreement with the maximum $\mathrm{PM}_{10}$ observation $\left(370 \mu \mathrm{g} \mathrm{m}^{-3}\right)$ registered during the same period. The minimum simulated surface concentration $\left(31 \mu \mathrm{g} \mathrm{m}^{-3}\right)$ is obtained in September, but the minimum $\mathrm{PM}_{10}$ concentration $\left(21 \mu \mathrm{g} \mathrm{m}^{-3}\right)$ is observed in $\mathrm{Au}-$ gust. The square of the correlation coefficient registered for Banizoumbou is 0.473 , with the slope of the tendency curve 0.722. Over Cinzana, a good correlation is obtained between the monthly simulated surface concentration and the $\mathrm{PM}_{10}$ observation, especially from March to October. The maximum simulated surface concentration and observation is obtained in March $\left(278 \mu \mathrm{g} \mathrm{m}^{-3}\right.$ for ALADIN and 
$257 \mu \mathrm{g} \mathrm{m}^{-3}$ for $\mathrm{PM}_{10}$ ). The minimum surface concentration $\left(25 \mu \mathrm{g} \mathrm{m}^{-3}\right)$ is simulated in September, and the minimum $\mathrm{PM}_{10}$ concentration $\left(15 \mu \mathrm{g} \mathrm{m}^{-3}\right)$ is observed in August. For this site, the correlation coefficient and the slope of the tendency curve are equal 0.648 and 0.894 , respectively. Over Mbour, the monthly simulated surface concentrations are larger than the observations over all months, except in July and August, when the slope of the tendency curve exceeds 1.566. ALADIN simulates the maximum concentration in January $\left(299 \mu \mathrm{g} \mathrm{m}^{-3}\right)$, but the maximum $\mathrm{PM}_{10}$ is observed in March $\left(202 \mu \mathrm{g} \mathrm{m}^{-3}\right)$. The minimum surface concentration $\left(23 \mu \mathrm{g} \mathrm{m}^{-3}\right)$ is simulated in August and the minimum $\mathrm{PM}_{10}$ concentration $\left(39 \mathrm{ug} \mathrm{m}^{-3}\right)$ is observed in September. The correlation coefficient obtained over Mbour is equal 0.804 .

It is worth mentioning that the dust surface concentration is strongly linked with the surface dust emission activity. Thus, the largest values for surface concentrations are registered in spring and winter, which correspond to the period of strong dust emission activity in the Sahelian region.

\subsection{Comparison to CALIOP observations}

In this section we use the CALIOP Level 2 Layer version 3.01 product (Koffi et al., 2012) over the 2007-2009 period to evaluate the ALADIN vertical distribution of dust aerosols. These data were previously used in Koffi et al. (2012) to evaluate the 12 AeroCom-I (Aerosol Comparison between observations and models, phase I) models over 13 subcontinental regions. In this study, the ALADIN-CALIOP intercomparison was limited to the northern African (NAF) and central African (CAF) regions. Note that the ALADIN model domain does not completely cover these two regions. Therefore, in our case, these two regions are defined as follows: 2$15^{\circ} \mathrm{N}, 18^{\circ} \mathrm{W}-48^{\circ} \mathrm{E}$ for $\mathrm{CAF}$ and $15-35^{\circ} \mathrm{N}, 18^{\circ} \mathrm{W}-48^{\circ} \mathrm{E}$ for NAF for ALADIN. For CALIOP, the same regions as those defined by Koffi et al. (2012) are used: $0-15^{\circ} \mathrm{N}, 18^{\circ} \mathrm{W}-$ $60^{\circ} \mathrm{E}$ for $\mathrm{CAF}$ and $15-35^{\circ} \mathrm{N}, 18^{\circ} \mathrm{W}-60^{\circ} \mathrm{E}$ for NAF. The seasonal dust aerosol mean extinction profiles from CALIOP observations (at 532) from January 2007 to December 2009 over these two regions are available at http://aerocom.met. no/download/CALIOP_BENCHMARK_KOFFI2012/.

Following Koffi at al. (2012), we calculate the mean extinction height $Z_{\alpha}$ over the lowest $10 \mathrm{~km}$ of the atmosphere in order to assess ALADIN's ability to reproduce the mean vertical distribution of dust aerosols over CAF and NAF. The following formula is used for computing $Z_{\alpha}$ :

$$
Z_{\alpha}=\frac{\sum_{i=1}^{n} b_{\mathrm{ext}, i} \cdot Z_{i}}{\sum_{i=1}^{n} b_{\mathrm{ext}, i}},
$$

where $b_{\text {ext, } i}$ is the aerosol extinction coefficient $\left(\mathrm{km}^{-1}\right)$ at level $i$ and $\mathrm{Z}_{i}$ the altitude $(\mathrm{km})$ of level $i$. The sums apply to the first $10 \mathrm{~km}$ of the atmosphere.
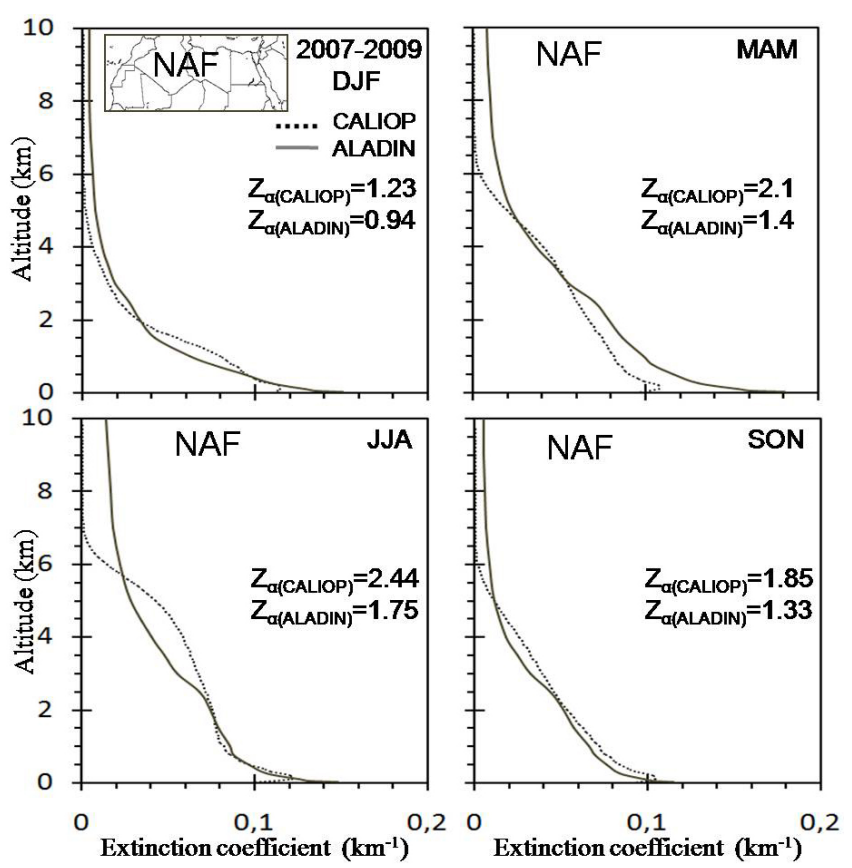

Figure 15. CALIOP and ALADIN mean seasonal extinction coefficient $\left(\mathrm{km}^{-1}\right)$ profiles (at 532 and $550 \mathrm{~nm}$, respectively) averaged from 2007 to 2009 over northern Africa (NAF). CALIOP profiles are shown as dark dashed lines and ALADIN profiles are shown as continuous grey lines. For each season, we give the $Z_{\alpha}$ value for CALIOP and ALADIN.

Figure 15 shows the CALIOP and ALADIN mean seasonal extinction coefficient profiles for NAF. The analysis of the CALIOP measurements allows the seasonal variability in the dust aerosols profile over NAF to be assessed. In winter, large values for dust aerosol extinction coefficients are observed between the ground and $2 \mathrm{~km}$ up; these lead to values of $Z_{\alpha}$ of about $1.23 \mathrm{~km}$. In spring and summer, the vertical mixing and the activity of sandstorms are at their maximum. Thus, in summer, $Z_{\alpha}(2.44 \mathrm{~km})$ is twice as large as in winter. In autumn, the decrease in dust activity is reflected by a value of $Z_{\alpha}$ of $1.85 \mathrm{~km}$.

This seasonality also exists for the CAF region (Fig. 16). The maximum of $Z_{\alpha}$ is obtained in June-July-August $(2.39 \mathrm{~km})$, with a bimodal vertical distribution. The second peak is located at around $3.5 \mathrm{~km}$ up. Koffi et al. (2012) explain this feature by the long-range transport of mineral dust from the Sahara and Sahel regions and the cross-hemispheric transport of biomass-burning products from southern Africa, which contribute to the aerosol load in the free troposphere.

Over the NAF region, the ALADIN model reproduces both the shape and the seasonality of the extinction coefficient profiles rather well. Note that in spring, ALADIN overestimates the extinction coefficient in the first $2 \mathrm{~km}$. At the surface, ALADIN simulates a peak of about $0.18 \mathrm{~km}^{-1}$, while the value measured by CALIOP does not exceed $0.11 \mathrm{~km}^{-1}$. Above $6 \mathrm{~km}$ of altitude, ALADIN overestimates 

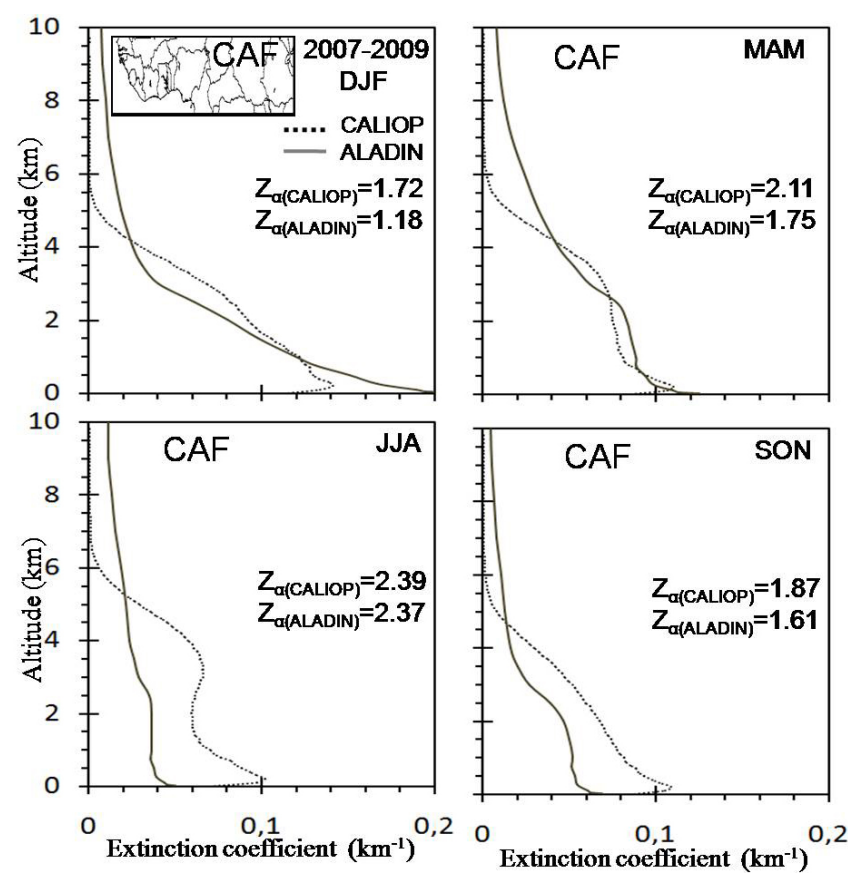

Figure 16. CALIOP and ALADIN mean seasonal extinction coefficient $\left(\mathrm{km}^{-1}\right)$ profiles (at 532 and $550 \mathrm{~nm}$, respectively) averaged from 2007 to 2009 over central Africa (CAF). CALIOP profiles are shown as dark dashed lines and ALADIN profiles are shown as continuous grey lines. For each season, we give the $Z_{\alpha}$ value for CALIOP and ALADIN.

the extinction coefficient for all seasons. ALADIN underestimates $Z_{\alpha}$, over all seasons in the NAF region, with a maximum of $Z_{\alpha}(1.75 \mathrm{~km})$ simulated in summer, in accordance with the CALIOP data.

Over the CAF region, significant differences are observed in the shape of the CALIOP and ALADIN extinction profiles. In winter, large extinction coefficient values $\left(>0.2 \mathrm{~km}^{-1}\right)$ are simulated by ALADIN in the first kilometre. This is in connection with the overestimation of surface dust concentration by ALADIN in this region. Note that the three measurement sites of dust concentration investigated in Sect. 4.3 (Banizoumbou, Cinzana and Mbour) are located in this region. In summer and autumn, ALADIN greatly underestimates the extinction coefficient in the first $5 \mathrm{~km}$. The reason here is that, in addition to dust aerosol, the CALIOP measurements are affected by other aerosols, such as biomassburning products, which contribute to an increase in the extinction coefficient. Note that the $Z_{\alpha}$ values simulated by ALADIN are underestimated for all seasons over the CAF region.

\section{Conclusions}

This study focuses on the elaboration and interpretation of a dust aerosol climatology for northern Africa using an operational numerical weather prediction model. The use of an NWP model for this type of study is novel and allows a better representation of the coupled processes between the surface and the atmosphere (emission by density currents, topographic forcing) and of the mesoscale processes. The simulated climatology enables us to assess the location of the main areas of dust emission and dry and wet deposition and provides a 3-D distribution of monthly dust aerosol optical properties over this region.

Results of 5-year simulations for the 2006-2010 period are presented. The annual dust emission in northern Africa estimated by ALADIN is about $878 \mathrm{Tg}_{\text {year }}{ }^{-1}$. The Bodélé Depression appears as the most important dust source region in northern Africa, with a total annual emission of $21.4 \mathrm{Tg}$ year $^{-1}$. Dust emission over northern Africa is characterized by strong seasonal variability. The emission is important in spring $(296 \mathrm{Tg})$ and summer $(233 \mathrm{Tg})$ and drops in winter and autumn to about 196 and $150 \mathrm{Tg}$, respectively.

The principal dry deposition areas are located near dust source emissions. Thus, in the Bodélé Depression, the mass of dry dust deposition corresponds to about half of the annual dust emission (400-800 $\mathrm{g} \mathrm{m}^{-2}$ year $^{-1}$ ). The southern limit of the dry deposition area is modulated by the position of the ITCZ. In winter, the extension of the dry deposition areas is very significant, especially towards the south and west of the Sahara. In summer, the southern limit of the area of dust deposition is located around $15^{\circ} \mathrm{N}$ and is connected to the establishment of the West African monsoon. The major wet deposition regions depend mainly on the distribution of large-scale and convective precipitation and the direction of dust plume transport. They are located in the southern part of northern Africa (Sahel, Gulf of Guinea, central Africa and the Atlantic Ocean). In winter, the wet deposition is very active $\left(10\right.$ to $\left.60 \mathrm{~g} \mathrm{~m}^{-2}\right)$ in the band from 2 to $10^{\circ} \mathrm{N}$ over the Gulf of Guinea and the Atlantic Ocean. In spring, wet deposition does not exceed $40 \mathrm{~g} \mathrm{~m}^{-2}$ over all of northern Africa. In summer, wet deposition is very active, with a maximum simulated over the Bodélé Depression and southern Niger $\left(140 \mathrm{~g} \mathrm{~m}^{-2}\right)$. These findings are consistent with the existence of large convective systems over the Sahelian regions in this season.

The simulated seasonal cycle of the AOT is in good agreement with MODIS observations. ALADIN generates prominent features of geographical patterns and seasonal variations that are in good agreement with the observations. The monthly AOT climatology presented in this paper is characterized by two AOT maxima exceeding 1.2. The first is simulated over the Sahel in March and the second in Mauritania and Mali in July. Low AOTs are simulated in autumn, again in accordance with MODIS observations. 
The vertical distribution of dust aerosol is characterized by a large concentration of dust aerosol at low levels between 0 and $100 \mathrm{~m}$. The maximum of the extinction coefficient is simulated in March.

The comparison of the simulated AOTs with ground AERONET measurements generally shows a good correlation at a remote site (Cape Verde). However, an overestimation of AOTs is observed in winter at sites located in the vicinity of dust source regions (Banizoumbou, Cinzana and Soroa). This overestimation suggests that the content of atmospheric dust is also overestimated in these source areas in winter. There are two possible reasons here: either the ALADIN model overestimates dust emission, or it underestimates the removal processes. In the first case, a possibly overly large emission may be due to an overly low threshold friction velocity simulated by the ALADIN model so that the mobilization occurs at an overly low wind speed.

ALADIN simulates the temporal pattern of monthly surface concentrations well but overestimates them from late autumn to late winter at all sites. As for the extinction coefficients, ALADIN reproduces both the shape and the seasonal variability in extinction coefficient profiles well, especially over the NAF region. In contrast, significant differences between the CALIOP and ALADIN extinction profiles are obtained over the CAF region. Indeed, this region is affected by salt and biomass-burning products, which heavily influence the extinction coefficients.

It is interesting to note that, despite the absence of any data assimilation process for dust content in ALADIN, the simulations remain overall satisfactorily correlated with observations. This result suggests that the model, whose initial and lateral boundary conditions are regularly refreshed by the global model ARPEGE, does not generate any significant drift of dust content over the whole 5-year range of the simulations.

Furthermore, the model seems able to maintain a correct relative impact of emission and deposition processes, which is reflected by the realistic characteristics of the predicted AOT fields.

In future, ALADIN's ability to simulate the dust aerosol content over the Mediterranean Sea will be investigated. For this purpose, the model will be tested within the framework of the ChArMEx (Chemistry-Aerosol Mediterranean Experiment) programme (http://mistrals.sedoo.fr/ChArMEx) over the Mediterranean Basin and will be compared with regional climate models over this region.

Acknowledgements. This paper is dedicated to the memory of Laurent Gomes.

Based on a French initiative, AMMA was built by an international scientific group and is currently funded by a large number of agencies, especially from France, the United Kingdom, the USA and Africa. It has been the beneficiary of a major financial contribution from the European Community's Sixth Framework Research Programme. Detailed information on scientific co- ordination and funding is available on the AMMA International web site http://www.amma-international.org. We also acknowledge the MODIS mission scientists and associated NASA personnel for the production of the data used in this research effort. This work was supported by the Algerian Met Office (ONM), Météo France, Centre National de Recherches Météorologiques (CNRM) and the French Embassy in Algeria.

Edited by: A. Geer

\section{References}

Albrecht, B. A.: Aerosols, cloud microphysics, and fractional cloudiness, Science, 245, 1227-1230, 1989.

Al-Saadi, J., Szykman, J., Pierce, R. B., Kittaka, C., Neil, D., Chu, D. A., Remer, L. A., Gumley, L., Prins, E., Weinstock, L., MacDonald, C., Wayland, R., Dimmick, F., and Fishman, J.: Improving national air quality forecasts with satellite aerosol observations, Bull. Am. Meteorol. Soc., 86, 1249-1261, doi:10.1175/BAMS-86-9-1249, 2005.

Bagnold, R. A.: The Physics of Blown Sand and Desert Dunes, Methuen, New York, 265 pp., 1941.

Bechtold, P., Bazile, E., Guichard, F., Mascart, P., and Richard, E.: A Mass flux convection scheme for regional and global models, Q. J. R. Meteorol. Soc. 127, 869-886, 2001.

Binkowski, F. S. and Roselle, S.: Models-3 community multiscale air quality (cmaq) model aerosol component 1, model description, J. Geophys Res., 108, 4183, doi:10.1029/2001JD001409, 2003.

Bougeault, P.: A simple parameterization of the large-scale effects of cumulus convection, Mon. Weather Rev., 113, 2108-2121, 1985.

Bougeault, P. and Lacarrère, P.: Parameterization of orographyinduced turbulence in a mesobeta-scale model, Mon. Weather Rev., 117, 1872-1890, 1989.

Bouteloup, Y., Bouyssel, F., and Marquet, P. : Improvments of Lopez's prognostic large scale cloud and precipitation scheme, ALADIN Newsletter, 28, 66-73, 2005.

Bréon, F. M., Vermeulen, A., and Descloitres, J.: An evaluation of satellite aerosol products against sunphotometers measurements, Remote Sens. Environ., 115, 3102-3111, doi:10.1016/j.rse.2011.06.017, 2011.

Brooks, N. P. and Legrand, M.: Dust variability over Northern Africa and rainfall in Sahel, in linking the climate change to landsurface change, Kluwer Academic Publishers, Dordecht, Netherlands, 1-25 pp., 2000.

Bubnová, R., Hello, G., Bénard, P., and Geleyn, J. F.: Integration of the fully elastic equations cast in the hydrostatic pressure terrain following coordinate in the framework of the ALADIN NWP system, Mon. Weather Rev., 123, 515-535, 1995.

Callot, Y., Marticorena, B., and Bergametti, G.: Geomorphologic approach for modelling the surface features of arid environments in a model of dust emission: application to the Sahara desert, Geodin. Acta, 13, 245-270, 2000.

Catry, B., Geleyn, J. F., Bouyssel, F., Cedilnik, J., Brozkova, R., Derkova, M., and Mladek, R.: A new sub-grid scale lift formulation in a mountain drag parametarisation scheme, Meteorol. Z., 17, 193-208, 2008. 
Chepil, W. S.: Properties of soil which influence wind erosion: IV. State or dry aggregate structure, Soil Sci., 72, 387-401, 1951.

Chin, M., Jacob, D. J., Gardner, G. M., Foreman-Fowler, M. S., Spiro, P. A., and Savoie, D. L.: A global three-dimensional model of tropospheric sulfate, J. Geophys. Res., 101, 18667-18690, doi:10.1029/96JD01221, 1996.

Crumeyrolle, S., Gomes, L., Tulet, P., Matsuki, A., Schwarzenboeck, A., and Crahan, K.: Increase of the aerosol hygroscopicity by cloud processing in a mesoscale convective system: a case study from the AMMA campaign, Atmos. Chem. Phys., 8, 6907-6924, doi:10.5194/acp-8-6907-2008, 2008.

Crumeyrolle, S., Tulet, P., Gomes, L., Garcia-Carreras, L., Flamant, C., Parker, D. J., Matsuki, A., Formenti, P., and Schwarzenboeck, A.: Transport of dust particles from the Bodélé region to the monsoon layer - AMMA case study of the 9-14 June 2006 period, Atmos. Chem. Phys., 11, 479-494, doi:10.5194/acp-11479-2011, 2011.

Cuxart, J., Bougeault, P., and Redelsperger, J. L.: A turbulence scheme allowing for mesoscale and large-eddy simulations, Q. J. R. Meteorol. Soc., 126, 1-30, 2000.

d'Almeida, G. A.: A model for Saharan dust transport, J. Clim. Appl. Meteorol., 25, 903-916, 1986.

Dirksen, R. J., Boersma, K. F., de Laat, J., Stammes, P., van der Werf, G. R., Val Martin, M., and Kelder, H. M.: An aerosol boomerang: rapid around-the-world transport of smoke from the December 2006 Australian forest fires observed from space, J. Geophys. Res., 114, D21201, doi:10.1029/2009JD012360, 2009.

Engel-Cox, J. A., Hoff, R. M., Rogers, R., Dimmick, F., Rush, A. C., Szykman, J. J., Al-Saadi, J., Chu, D. A., and Zell, E. R.: Integrating LIDAR and satellite optical depth with ambient monitoring for 3-D dimensional particulate characterization, Atmos. Environ., 40, 8056-8067, 2006.

Engelstaedter, S., Tegen, I., and Washington, R.: North African dust emissions and transport, Earth-Sci. Rev., 79, 73-100, 2006.

Flamant, C., Chaboureau, J.-P., Parker, D. J., Taylor, C. M., Cammas, J.-P., Bock, O., Timouk, P., and Pelon, J.: Airborne observations of the impact of a convective system on the planetary boundary layer thermodynamics and aerosol distribution in the intertropical discontinuity region of the West African monsoon, Q. J. R. Meteorol. Soc., 133, 1-28, 2007.

Fouquart, Y. and Bonnel, B.: Computations of solar heating of the earth's atmosphere: a new parameterization, Beitr. Phys. Atmosph., 53, 35-62, 1980.

Ginoux, P., Prospero, J. M., Torres, O., and Chin, M.: Long-term simulation of global dust distribution with the GOCART model: correlation with North Atlantic Oscillation, Environ. Model. Software, 19, 113-128, 2004.

Grini, A., Tulet, P., and Gomes, L.: Dusty weather forecasts using the MesoNH mesoscale atmospheric model, J. Geophys. Res., 111, D19205, doi:10.1029/2005JD007007, 2006.

Haywood, J. M., Francis, P. N., Glew, M. D., and Taylor, J. P.: Optical properties and direct radiative effect of Saharan dust: a case study of two Saharan dust outbreaks using aircraft data. J. Geophys. Res. Atmos., 106, 18417-18430, 2001.

Holben, B. N., Eck, T. F., Slutsker, I., Tanré, D., Buis, J. P., Setzer, A., Vermote, E., Reagan, J. A., Kaufman, Y., Nakajima, T., Lavenu, F., Jankowiak, I., and Smirnov, A.: AERONET-A Federated Instrument Network and Data Archive for Aerosol Charac- terization, Remote Sens. Environ., 66, 1-16, doi:10.1016/S00344257(98)00031-5, 1998.

Holben, B. N., Tanre, D., Smirnov, A., Eck, T. F., Slutsker, I., Abuhassan, N., Newcomb, W. W., Schafer, J., Chatenet, B., Lavenu, F., Kaufman, Y., Van de Castle, J., Setzer, A., Markham, B., Clark, D., Frouin, R., Halthore, R., Karnieli, A., O’Neill, N. T., Pietras, C., Pinker, R. T., Voss, K., and Zibordi, G.: An emerging ground-based aerosol climatology: Aerosol Optical Depth from AERONET, J. Geophys. Res., 106, 12067-12098, 2001.

Houghton, J., Ding, Y., Griggs, D. J., Noguer, M., Vander Linden, P. J., Dai, X., Maskell, K., and Johnon, C. A.: Climate Change 2001: The Scientific Basis. Cambridge University Press, New York, 2001.

Hsu, N. C., Tsay, S. C., King, M., and Herman, J. R.: Aerosol properties over bright-reflecting source regions, IEEE. T. Geosci. Remote, 42, 557-569, doi:10.1109/TGRS.2004.824067, 2004.

Hsu, N. C., Tsay, S., King, M. D., and Herman, J. R.: Deep Blue Retrievals of Asian Aerosol Properties During ACE-Asia, IEEE T. Geosci. Remote, 44, 3180-3195, 2006.

Hunt, W. H., Winker, D. M., Vaughan, M. A., Powell, K. A., Lucker, P. L., and Weimer, C.: CALIPSO lidar description and performance assessment, J. Atmos. Ocean. Tech., 26, 1214-1228, doi:10.1175/2009jtecha1223.1, 2009.

Intergovernmental Panel on Climate Control (IPCC): Climate Change 2007: The Physical Basis, in: Changes in Atmospheric Constituents and in Radiative Forcing, the Fourth, Assessment Report of the IPCC, edited by: Forster, P., Ramaswamy, V., Artaxo, R., Berntsen, T., Betts, R., Fahey, D. W., Haywood, J., Lean, J., Lowe, D. C., Myhre, G., Nganga, J., Prinn, R., Raga, G., Schulz, M., and Van Dorland, R.: Cambridge University Press, Cambridge, UK and New York, NY, USA, 129-234 pp., 2007.

Intergovernmental Panel on Climate Change (IPCC): Climate Change 2013: The Physical Science Basis in: Clouds and Aerosols, Contribution of Working Group I to the Fifth Assessment Report of the Intergovernmental Panel on Climate Change, edited by: Stocker, T. F., Qin, D., Plattner, G.-K., Tignor, M., Allen, S. K., Boschung, J., Nauels, A., Xia, Y., Bex, V., and Midgley, P. M., Boucher, O., Randall, D., Artaxo, P., Bretherton, C., Feingold, G., Forster, P., Kerminen, V.-M., Kondo, Y., Liao, H., Lohmann, U., Rasch, P., Satheesh, S. K., Sherwood, S., Stevens, B., and Zhang, X. Y.: Cambridge University Press, Cambridge, United Kingdom and New York, NY, USA, 1535 pp., doi:10.1017/CBO9781107415324, 2013.

Kaufman, Y. J., Koren, I., Remer, L. A., Tanré, D., Ginoux, P., and Fan, S.: Dust transport and deposition observed from the Terra-Moderate Resolution Imaging Spectroradiometer (MODIS) spacecraft over the Atlantic Ocean, J. Geophys. Res. 110, D10S12, doi:10.1029/2003JD004436, 2005.

Kinne, S., Schulz, M., Textor, C., Guibert, S., Balkanski, Y., Bauer, S. E., Berntsen, T., Berglen, T. F., Boucher, O., Chin, M., Collins, W., Dentener, F., Diehl, T., Easter, R., Feichter, J., Fillmore, D., Ghan, S., Ginoux, P., Gong, S., Grini, A., Hendricks, J., Herzog, M., Horowitz, L., Isaksen, I., Iversen, T., Kirkevåg, A., Kloster, S., Koch, D., Kristjansson, J. E., Krol, M., Lauer, A., Lamarque, J. F., Lesins, G., Liu, X., Lohmann, U., Montanaro, V., Myhre, G., Penner, J., Pitari, G., Reddy, S., Seland, O., Stier, P., Takemura, T., and Tie, X.: An AeroCom initial assessment - optical properties in aerosol component modules of global models, At- 
mos. Chem. Phys., 6, 1815-1834, doi:10.5194/acp-6-1815-2006, 2006.

Kinne, S., O’Donnel, D., Stier, P., Kloster, S., Zhang, K., Schmidt, H., Rast, S., Giorgetta, M., Eck, T. F., and Stevens, B.: MACv1: A new global aerosol climatology for climate studies, J. Adv. Model. Earth Syst., 5. 704-740, doi:10.1002/jame.20035, 2013.

Knippertz, P. and Todd, M. C.: Mineral dust aerosols over the Sahara: Meteorological controls on emission and transport and implications for modeling, Rev. Geophys., 50, RG1007, doi:10.1029/2011RG000362, 2012.

Kocha, C., Lafore, J. P., Tulet, P., and Seity, Y.: High resolution simulation of a major West African dust storm: Comparison with observations and investigation of dust impact, Q. J. R. Meteorol. Soc., 138, 455-470, doi:10.1002/qj.927, 2012.

Kocha, C., Tulet, P., Lafore, J. P., and Flamant, C.: The importance of the diurnal cycle of Aerosol Optical Depth in West Africa, Geophys. Res. Lett., 40, 785-790, doi:10.1002/grl.50143, 2013.

Koffi, B., Schulz, M., Bréon, F.-M., Griesfeller, J., Winker, D. M. M., Balkanski, Y., Bauer, S., Berntsen, T., Chin, M., Collins, W. D., Dentener, F., Diehl, T., Easter, R.C., Ghan, S. J., Ginoux, P. A., Gong, S., Horowitz, L. W., Iversen, T., Kirkevag, A., Koch, D.M., Krol, M., Myhre, G., Stier, P., and Takemura, T.: Application of the CALIOP Layer Product to evaluate the vertical distribution of aerosols estimated by global models: Part 1. AeroCom phase I results, J. Geophys. Res. 117, D10201, doi:10.1029/2011JD016858, 2012.

Laurent, B., Marticorena, B., Bergametti, G., Léon, J. F., and Mahowald, N. M.: Modeling mineral dust emissions from the Sahara desert using new surface properties and soil database. J. Geophys. Res., 113, D14218, doi:10.1029/2007JD009484, 2008.

Levy, R. C., Remer, L. A., Mattoo, S., Vermote, E. F., and Kaufman, Y. J.: Second-generation operational algorithm: Retrieval of aerosol properties over land from inversion of Moderate Resolution Imaging Spectroradiometer spectral reflectance, J. Geophys. Res., 112, D13211, doi:10.1029/2006JD007811, 2007.

Levy, R. C., Remer, L. A., Kleidman, R. G., Mattoo, S., Ichoku, C., Kahn, R., and Eck, T. F.: Global evaluation of the Collection 5 MODIS dark-target aerosol products over land, Atmos. Chem. Phys., 10, 10399-10420, doi:10.5194/acp-10-10399-2010, 2010.

Levy, R. C., Mattoo, S., Munchak, L. A., Remer, L. A., Sayer, A. M., Patadia, F., and Hsu, N. C.: The Collection 6 MODIS aerosol products over land and ocean, Atmos. Meas. Tech., 6, 29893034, doi:10.5194/amt-6-2989-2013, 2013.

Li, Z., Xia, X., Cribb, M., Mi, W., Holben, B., Wang, P., Chen, H., Tsay, S., Eck, T. F., Zhao, F., E. G. Dutton E. G., and Dickerson, R. E.: Aerosol optical properties and their radiative effects in northern China, J. Geophys. Res., 112, D22S01, doi:10.1029/2006JD007382, 2007.

Liousse, C., Penner, J. E., Chuang, C., Walton, J. J., Eddleman, H., and Cachier, H.: A global three-dimensional model study of carbonaceous aerosols, J. Geophys. Res. 101, 19411-19432, doi:10.1029/95JD03426, 1996.

Lopez, P.: Implementation and validation of a new prognostic large-scale cloud and precipitation scheme for climate and dataassimilation purposes, Q. J. R. Meteorol. Soc., 128, 229-257, 2002.

Luo, C., Mahowald, N. M., and del Corral, J.: Sensitivity study of meteorological parameters on mineral aerosol mobiliza- tion, transport, and distribution, J. Geophys. Res. 108, 4447, doi:10.1029/2003JD003483, 2003.

Mallet, M., Tulet, P., Serça, D., Solmon, F., Dubovik, O., Pelon, J., Pont, V., and Thouron, O.: Impact of dust aerosols on the radiative budget, surface heat fluxes, heating rate profiles and convective activity over West Africa during March 2006, Atmos. Chem. Phys., 9, 7143-7160, doi:10.5194/acp-9-7143-2009, 2009.

Marticorena, B. and Bergametti, G.: Modeling the atmospheric dust cycle: 1. Design of a soil-derived dust emission scheme, J. Geophys. Res., 100, 16415-16430, 1995.

Marticorena, B. and Bergametti, G.: Two year simulations of seasonal and interannual changes in Saharan dust emissions, Geophys. Res. Lett., 23, 1921-1924, 1996.

Marticorena, B., Chatenet, B., Rajot, J. L., Traoré, S., Coulibaly, M., Diallo, A., Koné, I., Maman, A., NDiaye, T., and Zakou, A.: Temporal variability of mineral dust concentrations over West Africa: analyses of a pluriannual monitoring from the AMMA Sahelian Dust Transect, Atmos. Chem. Phys., 10, 8899-8915, doi:10.5194/acp-10-8899-2010, 2010.

Martin, J. H.: Iron still comes from above, Nature, 353, p. 123 , doi:10.1038/353123b0, 1991.

Martin, R. V., Jacob, D. J., Yantosca, R. M., Chin, M., and Ginoux, P.: Global and regional de-creases in tropospheric oxidants from photo-chemical effects of aerosols, J. Geophys. Res., 108, 4097, doi:10.1029/2002JD002622, 2003.

Masson, V., Champeaux, J., Chauvin, F., Meriguet, C., and Lacaze, R.: A global database of land surface parameters at 1-km resolution in meteorological and climate models, J. Climate, 16, 12611282, 2003.

Masson, V., Le Moigne, P., Martin, E., Faroux, S., Alias, A., Alkama, R., Belamari, S., Barbu, A., Boone, A., Bouyssel, F., Brousseau, P., Brun, E., Calvet, J.-C., Carrer, D., Decharme, B., Delire, C., Donier, S., Essaouini, K., Gibelin, A.-L., Giordani, H., Habets, F., Jidane, M., Kerdraon, G., Kourzeneva, E., Lafaysse, M., Lafont, S., Lebeaupin Brossier, C., Lemonsu, A., Mahfouf, J.-F., Marguinaud, P., Mokhtari, M., Morin, S., Pigeon, G., Salgado, R., Seity, Y., Taillefer, F., Tanguy, G., Tulet, P., Vincendon, B., Vionnet, V., and Voldoire, A.: The SURFEXv7.2 land and ocean surface platform for coupled or offline simulation of earth surface variables and fluxes, Geosci. Model Dev., 6, 929-960, doi:10.5194/gmd-6-929-2013, 2013.

Meloni, D., Sarra, A. D., Di lorio, T., and Fiocco, G.: Influence of the vertical profile of Saharan dust on the visible direct radiative forcing, J. Quant. Spectr. Radiat. Trans., 93, 397-413, 2005.

Mlawer, E. J., Taubman, S. J., Brown, P. D., Iacono, M. J., and Clough, S. A.: RRTM, a validated correlated-k model for the longwave, J. Geophys. Res., 102, 16663-16682, 1997.

Mokhtari, M., Gomes, L., Tulet, P., and Rezoug, T.: Importance of the surface size distribution of erodible material: an improvement on the Dust Entrainment And Deposition (DEAD) Model, Geosci. Model Dev., 5, 581-598, doi:10.5194/gmd-5-581-2012, 2012.

Morcrette, J. J.: Radiation and cloud radiative properties in the ECMWF operational weather forecast model, J. Geophys. Res., 96D, 9121-9132, 1991.

Morcrette, J. J., Boucher, O., Jones, L., Salmond, D., Bechtold, P., Beljaars, A., Benedetti, A., Bonet, A., Kaiser, J. W., Razinger, M., Schulz, M., Serrar, S., Simmons, A. J., Sofiev, M., Suttie, M., Tompkins, A. M., and Untch, A.: Aerosol analysis and forecast 
in the European Centre for Medium-Range Weather Forecasts Integrated Forecast System: Forward modeling. J. Geophys. Res., 11, D06206, doi:10.1029/2008JD011235, 2009.

Nabat, P., Somot, S., Mallet, M., Chiapello, I., Morcrette, J. J., Solmon, F., Szopa, S., Dulac, F., Collins, W., Ghan, S., Horowitz, L. W., Lamarque, J. F., Lee, Y. H., Naik, V., Nagashima, T., Shindell, D., and Skeie, R.: A 4-D climatology (1979-2009) of the monthly tropospheric aerosol optical depth distribution over the Mediterranean region from a comparative evaluation and blending of remote sensing and model products, Atmos. Meas. Tech., 6, 1287-1314, doi:10.5194/amt-6-1287-2013, 2013.

Noilhan, J. and Planton, S.: A simple parameterization of land surface processes for meteorological models, Mon. Weather Rev., 117, 536-549, 1989.

Prospero, J. M., Ginoux, P., Torres, O., Nicholson, S. E., and Gill, T. E.: Environmental characterization of global sources of atmospheric soil dust identified with the nimbus 7 total ozone mapping spectrometer (toms) absorbing aerosol product, Rev. Geophys., 40, 1002, doi:10.1029/2000RG000095, 2002.

Radnóti, G.: Comments on "A spectral limited-area formulation with time-dependent boundary conditions applied to the shallowwater equations", Mon. Weather Rev., 123, 3122-3123, 1995.

Remer, L. A., Kaufman, Y. J., Tanré, D., Matoo, S., Chu, D. A., Martins, J. V., Li, R. R., Ichoku, C., Levy, R. C., Kieidman, R. G., Eck, T. F., Vermote, E., and Holben, B. N.: The MODIS Aerosol Algorithm, Products, and Validation, J. Atmos. Sci., 62, 947-73, doi:10.1175/JAS3385.1, 2005.

Rodwell, M.: The local and global impact of the recent change in model aerosol climatology, ECMWF Newsletter, 105, 17-23, 2005.

Rogers, R. R., Vaughan, M. A., Hostetler, C. A., Burton, S. P., Ferrare, R. A., Young, S. A., Hair, J. W., Obland, M. D., Harper, D. B., Cook, A. L., and Winker, D. M.: Looking through the haze: evaluating the CALIPSO level 2 aerosol optical depth using airborne high spectral resolution lidar data, Atmos. Meas. Tech., 7, 4317-340, doi:10.5194/amt-7-4317-2014, 2014.

Sandu, I., Brenguier, J., Geoffroy, O., Thouron, O., and Masson, V.: Aerosol impacts on the diurnal cycle of marine stratocumulus, J. Atmos. Sci., 65, 2705-2718, 2008.

Satheesh, S. K.: Letter to the Editor Aerosol radiative forcing over land: effect of surface and cloud reflection, Ann. Geophys., 20, 2105-2109, doi:10.5194/angeo-20-2105-2002, 2002.

Schepanski, K., Tegen, I., and Macke, A.: Comparison of satellite based observations of Saharan dust source areas, Remote Sens. Environ., 123, 90-97, 2012.

Schmechtig, C., Marticorena, B., Chatenet, B., Bergametti, G., Rajot, J. L., and Coman, A.: Simulation of the mineral dust content over Western Africa from the event to the annual scale with the CHIMERE-DUST model, Atmos. Chem. Phys., 11, 7185-7207, doi:10.5194/acp-11-7185-2011, 2011.

Seinfeld, J. H. and Pandis, S. N.: Atmospheric chemistry and physics: From Air Pollution to Climate Change, John Wiley, New York, 292-293, 1997.

Shi, Y., Zhang, J., Reid, J. S., Hyer, E. J., and Hsu, N. C.: Critical evaluation of the MODIS Deep Blue aerosol optical depth product for data assimilation over North Africa, Atmos. Meas. Tech., 6, 949-969, doi:10.5194/amt-6-949-2013, 2013.
Smith, R. N. B.: A scheme for predicting layer clouds and their water content in a general circulation model, Q. J .R. Meteorol. Soc., 116, 435-460, 1990.

Sokolik, I. N., Winker, D. M., Bergametti, G., Gillette, D. A., Carmichael, G., Kaufman, Y. J., Gomes, L., Schuetz, L., and Penner, J. E.: Introduction to special section: Outstanding prob-lems in quantifying the radiative impacts of mineral dust, J. Geophys. Res.-Atmos., 106, 18015-18027, 2001.

Stephens, G. L., Vane, D. G., Boain, R. J., Mace, G. G., Sassen, K., Wang, Z., Illingworth, A. J., O'Connor, E. J., Rossow, W. B., Durden, S. L., Miller, S. D., Austin, R. T., Benedetti, A., and Mitrescu, C.: The cloudsat mission and the A-Train: a new dimension of space-based observations of clouds and precipitation, B. Am. Meteorol. Soc., 83, 1771-1790, +1742, 2002.

Swap, R.M., Garstang, M., Greco, S., Talbot, R., and Kallberg, P.: Saharan dust in the Amazon basin, Tellus B, 44, 133-149, 1992.

Tanaka, T. Y. and Chiba, M.: Global Simulation of Dust Aerosol with a Chemical Transport Model, MASINGAR, J. Meteorol. Soc. Jpn., 83A, 255-278, 2005.

Tanré, D., Geleyn, J. F., and Slingo, J. M.: First results of the introduction of an advanced aerosol-radiation interaction in the ECMWF low resolution global model, in: Aerosols and Their Climatic Effects, edited by: Gerber, H. E., 133-177, A. Deepak, Hampton, Va, 1984.

Tanré, D., Kaufman, Y. J., Herman, M., and Mattoo, S.: Remote sensing of aerosol properties over oceans using the MODIS/EOS spectral radiances, J. Geophys. Res., 102, 16971-16988, 1997.

Tegen, I. and Fung, I.: Contribution to the atmospheric mineral aerosol load from land surface modification, J. Geophys. Res., 100, 18707-18726, doi:10.1029/95JD02051, 1995.

Tegen, I., Hollrig, P., Chin, M., Fung, I., Jacob, D., and Penner, J.: Contribution of different aerosol species to the global aerosol extinction optical thickness: Estimates from model results, J. Geophys. Res.m 102, 23895-23915, 1997.

Todd, M. C., Washington, R., Martins, J. V., Dubovik, O., Lizcano, G., M'Bainayel, S., and Engelstaedter, S.: Mineral dust emission from the Bodélé Depression, northern Chad, during BoDEx 2005, J. Geophys. Res., 112, D06207, doi:10.1029/2006JD007170, 2007.

Tompkins, A. M., Cardinali, C., Morcrette, J. J., and Rodwell, M.: Influence of aerosol climatology on forecasts of t he African Easterly Jet, Geophys. Res. Lett., 32, L10801, doi:10.1029/2004GL022189, 2005.

Tost, H., Jöckel, P., Kerkweg, A., Sander, R., and Lelieveld, J.: Technical note: A new comprehensive SCAVenging submodel for global atmospheric chemistry modelling, Atmos. Chem. Phys., 6, 565-574, doi:10.5194/acp-6-565-2006, 2006.

Tulet, P., Crassier, V., Cousin, F., Suhre, K., and Rosset, R.: ORILAM, a three-moment lognormal aerosol scheme for mesoscale atmospheric model: Online coupling into the MesoNH-C model and validation on the Escompte campaign, J. Geophys. Res., 110, D18201, doi:10.1029/2004JD005716, 2005.

Tulet, P., Mallet, M., Pont, V., Pelon, J., and Boone, A.: The $7-$ 13 March, 2006, dust storm over West Africa: generation, transport and vertical stratification, J. Geophys. Res., 113, D00C08, doi:10.1029/2008JD009871, 2008.

Tulet, P., Crahan-Kaku, K., Leriche, M., Aouizerats, B., and Crumeyrolle, S.: 2010. Mixing of dust aerosols into mesoscale convective system: Generation, filtering and pos- 
sible feedbacks on ice anvils, Atmos. Res., 96, 302-314, doi:10.1016/j.atmosres.2009.09.011, 2010.

Twomey, S.: The nuclei of natural cloud formation. II: The supersaturation in natural clouds and the variation of cloud droplet concentration, Pure d Appl. Geophys., 43, 243-249, 1959.

United States Department of Agriculture (USDA), Natural Resources Conservation Service (NRCS): Soil Taxonomy: A Basic System of Soil Classification for Making and Interpreting Soil Surveys Agr. Handb. 436. U.S. Govt. Print Office, Washington DC, 20402, 2nd Edn., 1999.

Wang, T., Cheung, T. F., Li, Y. S., Xu, X. M., and Blake, D. R.: Emission characteristics of $\mathrm{CO}, \mathrm{NOx}, \mathrm{SO}_{2}$ and indications of biomass burning observed at a rural site in eastern China, J. Geophys. Res., 107, 4157, doi:10.1029/2001JD000724, 2002.

Washington, R., Todd, M., Middleton, N. J., and Goudie, A. S.: Dust-Storm source areas determined by the total ozone monitoring spectrometer and surface observations, Ann. Assoc. Am. Geogr., 93, 297-313, 2003.

Washington, R., Todd, M. C., Engelstaedter, S., Mbainayel, S., and Mitchell, F.: Dust and the low-level circulation over the Bodélé depression, Chad: Observations from BoDEx 2005, J. Geophys. Res., 111, D03201, doi:10.1029/2005JD006502, 2006.
Werner, M., Tegen, I., Harrison, S. P., Kohfeld, K. E., Prentice, I. C., Balkanski, Y., Rodh, H., and Roelandt, C.: Seasonal and interannual variability of the mineral dust cycle under present and glacial climate conditions, J. Geophys. Res., 107, 4744, doi:10.1029/2002JD002365, 2002.

Wesely, M.: Parametrizations of surface resistance to gaseous dry deposition in regional scale, numerical models, Atmos. Environ., 23, 1293-1304, 1989.

Winker, D. M., Hunt, W. H., and McGill, M. J.: Initial performance assessment of CALIOP, Geophys. Res. Lett., 34, L19803, doi:10.1029/2007GL030135, 2007.

Zender, C. S., Bian, H., and Newman, D.: Mineral Dust Entrainment and deposition (DEAD) model: Description and 1990s dust climatology, J. Geophys. Res., 108, 4416, doi:10.1029/2002JD002775, 2003.

Zhu, A., Ramanathan, V., Li, F., and Kim, D.: Dust plumes over the Pacific, Indian, and Atlantic oceans: climatology and radiative impact, J. Geophys. Res., 112, D16208, doi:10.1029/2007JD008427, 2007. 